\title{
PMK-2, the First Integral Thermal-Hydraulics Tests for the Safety Evaluation of VVER-440/213 Nuclear Power Plants
}

\author{
Gy. Ézsöl, L. Perneczky, L. Szabados, and I. Tóth \\ Department of Thermohydraulics, MTA KFKI Atomic Energy Research Institute, P.O. Box 49, 1525 Budapest, Hungary \\ Correspondence should be addressed to Gy. Ézsöl, ezsol@aeki.kfki.hu
}

Received 20 May 2011; Accepted 5 August 2011

Academic Editor: Klaus Umminger

Copyright (C) 2012 Gy. Ézsöl et al. This is an open access article distributed under the Creative Commons Attribution License, which permits unrestricted use, distribution, and reproduction in any medium, provided the original work is properly cited.

\begin{abstract}
The PMK-2 facility is a full-pressure thermal-hydraulic model of the primary and partly the secondary circuit of the VVER-type units of Paks NPP. The facility was the first integral-type facility for VVERs. The PMK-2 was followed later by the PACTEL (for VVER-440), the ISB, and PSB for VVER-1000. Since the startup of the facility in 1985, 55 experiments have been performed primarily in international frameworks with the participation of experts from 29 European and overseas countries forming a scientific school to better understand VVER system behaviour and reach a high level of modelling of accident sequences. The ATHLET, CATHARE, and RELAP5 codes have been validated including both qualitative and quantitative assessments. The former was almost exclusively applied to the early phase of validation by integral experiments, while the quantitative assessments have been performed by the Fast Fourier Transform Based Method. Paper gives comprehensive information on the design features of PMK-2 facility with a special respect to the representativeness of phenomena, the experiments performed, and the results of the validation of ATHLET, CATHARE, and RELAP5 codes. Safety significance of the PMK-2 projects is also discussed.
\end{abstract}

\section{Introduction}

The PMK-2 projects were initiated in the early 1980's, parallel to the start-up procedures of the units of the Paks nuclear power plant of VVER-440/213 type. The vendor provided the safety report of the plant, however, without details of analyses, and with short information on the computer codes applied to the analyses. Therefore, to perform independent assessment of the safety of the plant in the country, there was an urgent need for tools of plant system analyses, that is, for thermohydraulic system codes and thermohydraulic system experiments to assess the predictive capabilities of codes. In the first part of the 1980's, an early version of the thermohydraulic system code RELAP was available through the IAEA. To get results of system tests for VVER-440/213 type NPPs, the design and construction of the PMK-2 facility were initiated, because, at that time, no integral-type facility existed for VVERs that is, PMK-2 (Paks Model Experiment) was the first and the only facility for VVERs. The facility was put into operation in 1985. The PMK-2 was followed by the
PACTEL facility for VVER-440 in Finland (1990) and the ISB and PSB facilities for VVER-1000 in Russia (1992 and 1998, resp.).

This report on the PMK-2 projects contains information providing comprehensive descriptions of the first integraltype research programme organized and conducted for VVER-440/213 nuclear power plants, primarily for the Paks nuclear power plant, to study design basis accidents, performing system experiments and getting expertise in code validation primarily through international standard problems, with the participation of experts of 29 countries from the whole world.

Report contains the description of design features of the PMK-2 facility, modelling of the VVER-440/213-specific design solutions, controls, and actions for safety systems. A description and evaluation is given in the 55 experiments performed, which cover an almost complete spectrum of design basis accidents (DBA) corresponding to the most recent version of the safety analysis report (SAR) of the Paks NPP. The OECD-VVER cross reference matrices are 
developed for the PMK-2 tests for large breaks, small and intermediate leaks, and transients, providing internationally accepted methodology for the identification of major phenomena addressed by the tests. Matrices contain test types occurring in transients and accidents.

Major findings of experiments include results of tests having safety significance, identified by the use of OECDVVER code validation matrices. In these matrices physical/ thermohydraulic phenomena are linked to test types or inversely. The main items of phenomena are as follows: break flow, pressuriser thermohydraulics, heat transfer in SG primary and secondary side, single- and two-phase natural circulation, mixing and condensation during injection from ECCSs, loop seal behaviour in hot leg and clearance in cold leg, core heat transfer including DNB, and dryout. Tests are selected from the cross-reference matrices applied to the PMK-2 tests for large breaks, small and intermediate leaks, and transients. Major findings identified give primarily the basis of the evaluation of the code prediction; that is, if an identified phenomenon is well predicted by the code, the assessment for this phenomenon is successful.

An effective way to increase the confidence in the validity and accuracy of computer codes can be provided by international standard problems (ISP), which were organized and conducted by the OECD/CSNI since 1975, and 20 tests for validation purposes had been performed in about 25 years. The IAEA Standard Problem Exercises were initiated in 1986, and four PMK-2 based exercises were conducted. These activities provided wide frameworks to assess the capabilities of computer codes to represent phenomena occurring in plant transients and accidents and offered a floor to exchange modelling expertise among the best specialists of the field.

Other international frameworks were provided by the EU-PHARE and EU-Framework projects, as well as the US NRC CAMP Program. Altogether 19 PMK-2 tests were applied to study the pressuriser thermohydraulics, large break in the hot leg, primary to secondary leaks, accident analysis methodologies, steam generator heat transfer, and the effectiveness of secondary and primary bleed and feed, as well as accident analysis methodologies.

Methodology and practice applied to the PMK-2 projects include qualitative and quantitative activities. The qualitative assessment is based on the engineering judgement, which means the comparison of the results of a test and computer code calculation, evaluating the results by visual observation. In the quantitative assessment, the comparison is made quantitatively. In the PMK-2 projects, the quantitative assessment is performed by the fast fourier transform based method (FFTBM).

The quantitative assessment is made by the Fast Fourier Transform Based Method (FFTBM) developed at the University of Pisa (Italy). The methodology and an FFTBM code had been implemented at the AEKI. This is a powerful technique for the quantification of the error between measured and calculated parameters of the transient processes, occurring in plants or in scaled-down facilities. The code provides the amplitude and weighted frequency of the deviation of measured and calculated quantities.

\section{The PMK-2 Facility: The First Integral-Type Facility for VVER-440/213 Plants}

The PMK-2 facility is located at the MTA KFKI Atomic Energy Research Institute, Budapest, Hungary. It is a fullpressure thermal-hydraulic model of the primary and partly the secondary circuit of VVER-440/213 type units of Paks NPP. At the start-up time of Paks NPP, PMK-2 was the first and only integral-type facility for VVERs. Modelling of specific design solutions and modelling aspects of PMK-2 are shortly given below. Details were published in [1-3].

2.1. Design Features of VVER-440/213-Type Reactor Systems. A schematic drawing of the primary circuit of the Paks NPP with one main circulating loop is presented in Figure 1. The six-loop primary circuit is equipped with VVER-440 reactors and horizontal steam generators (SGs) in each loop. The active length of the core is $2.5 \mathrm{~m}$; the number of fuel rods is 39,312 in hexagonal rod array with fuel assemblies consisting of 127 fuel rods in closed shrouds. The reactor control is achieved by control assemblies having the dimensions of fuel assemblies. The inner diameter of the reactor vessel is $3.5 \mathrm{~m}$.

It can be seen in Figure 1 that there are loop seals in both hot and cold legs. Like in PWRs, loop seal exists in the cold legs in consequence of the main circulating pumps (MCP), but also in the hot legs, because the six hot and cold legs are connected to the vessel at different elevations, forming Utubes with a depth of $1.4 \mathrm{~m}$. This specific feature affects the thermohydraulic behaviour of the system.

The steam generators in each loop are large horizontal vessels with a diameter of $3.2 \mathrm{~m}$. The inner diameter of the horizontal heat transfer tubes is $13.2 \mathrm{~mm}$ with an average length of $9 \mathrm{~m}$. The total number of tubes is 5536 in 77 rows with an overall height of $1.82 \mathrm{~m}$ of the tube bundles resulting in a large water volume in the secondary side of the SG.

The emergency core cooling systems (ECCSs) consist of four safety injection tanks (SITs), three parallel high-pressure injection systems (HPIS), and three parallel low-pressure injection systems (LPIS). The latter is activated at a system pressure of $0.7 \mathrm{MPa}$. The HPI systems are activated either by low system pressure or low water level in the pressuriser. The original SIT set-point pressure was $5.9 \mathrm{MPa}$, higher than the secondary pressure of $4.6 \mathrm{MPa}$. The inlet and outlet temperatures are 540 and $570 \mathrm{~K}$, respectively. The operating pressure is $12.3 \mathrm{MPa}$, and the core thermal power is $1375 \mathrm{MW}$.

2.2. Modelling Aspects of PMK-2. In most of the transients and accidents-especially in experiments in support of the development of accident management procedures-it is important to start the experiments from the nominal operating parameters of the plant; therefore, the PMK-2 is a full pressure/temperature facility, and the coolant is water. In the transient processes the control and safety signals of the plant are followed. For the design of the PMK-2 the volume scaling criteria were selected which would require the maintenance of the length, elevation, area, volume, and pressure drop relationships. However, it is not possible to maintain 


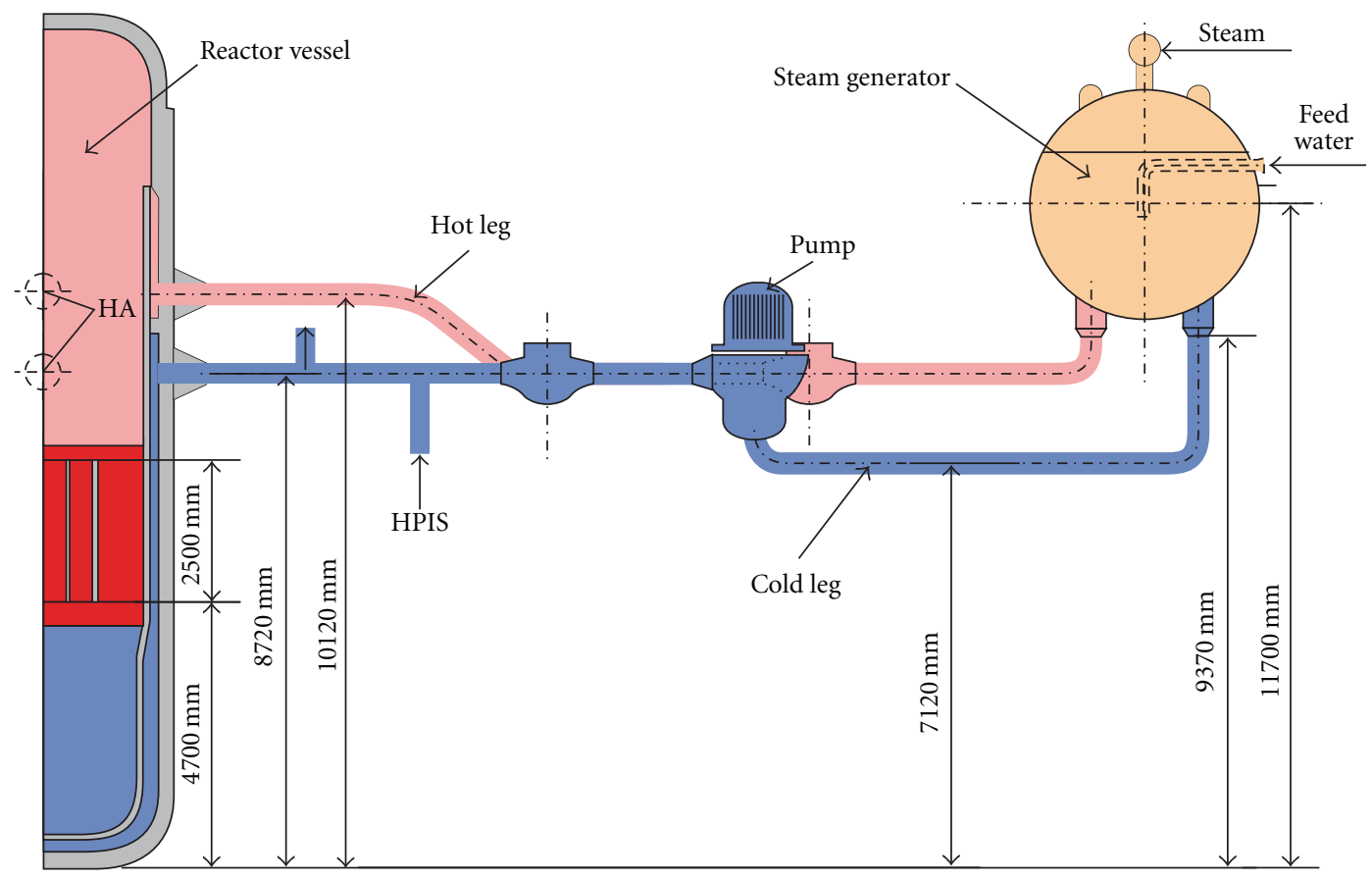

FIgURE 1: Schematic drawing of the primary circuit of the VVER-440 plant.

the requirements simultaneously; therefore, acceptable compromises are needed.

When the facility was designed in the early 1980s, the range of scaling ratios of integral-type thermohydraulic facilities was, for example, $1: 48$ for ROSA-IV in Japan and $1: 1705$ for SEMISCALE in the USA. Considering the scaling ratio interval and the financial possibilities of the country, a 19-rod core model with $2.5 \mathrm{~m}$ heated length was selected which gives the power ratio of $1: 2070(39312 / 19 \cong 2070)$, and, therefore, the overall volume scaling ratio is also $1: 2070$. Due to the importance of gravitational forces in natural circulation, the elevation ratio is $1: 1$. The scaling ratio is near to the SEMISCALE scaling ratio, which facility was successfully used for pretests in the LOFT project.

The six loops of the plant in the PMK-2 facility are lumped into a single loop, and the break is modelled by orifices of suitable sizes at the hot and cold leg elevations in the upper plenum and downcomer. From the component models the main design and similarity features of the core model, the steam generator model, and the hot leg model are presented.

The cross-section of the 19-rod core model is presented in Figure 2. The hexagonal fuel rod array with a fuel rod diameter of $9.1 \mathrm{~mm}$, a pitch of $12.2 \mathrm{~mm}$, and with a heated length of $2.5 \mathrm{~m}$ the same as in the reference system. However, the axial power distribution is uniform. In steady state the similarity of thermohydraulic processes in the core is ensured by the same operational parameters and the similar geometry. The similarity of natural circulation is evaluated by the scaling criteria obtained by Ishii and Kataoka [4] from the integral effects of local balance equations along the entire loop. These criteria for both single- and two-phase natural

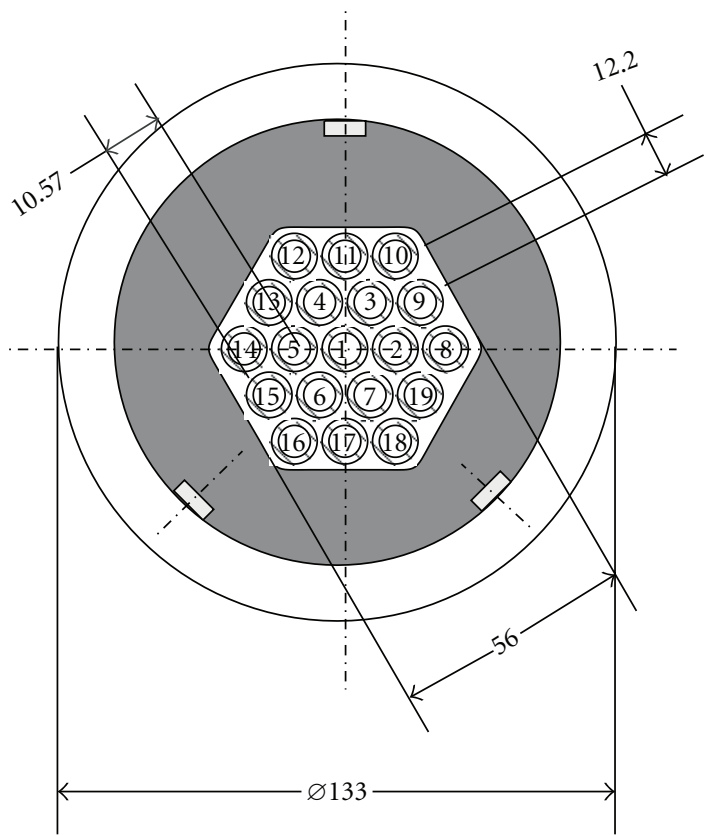

FiguRE 2: Cross section of the core model.

circulation are almost completely fulfilled for the core, except for the time ratio and Biot numbers due to the different fuel element structure of the model and the reference system.

The cross-section of the steam generator (SG) model is shown in Figure 3 with one of the 82 rows of the horizontal heat transfer tubes between the hot and cold collectors, with a length of $3715 \mathrm{~mm}$. The tube number, diameter, and length 


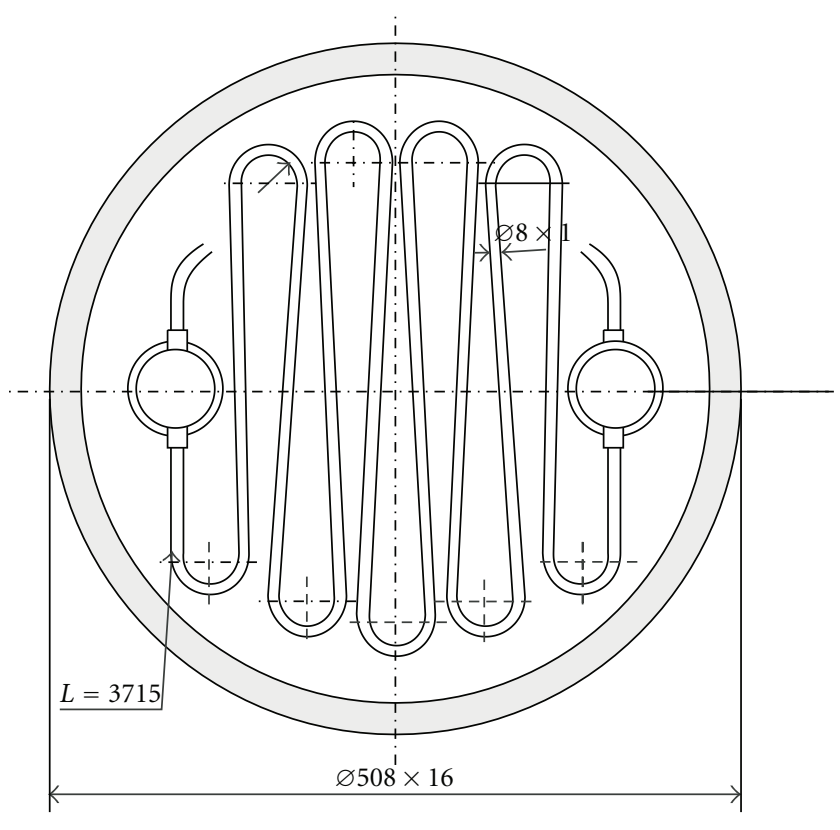

FIgURE 3: The cross section of the steam generator.

were determined by the requirement of volume scaling. The elevations of tube rows, the vertical surface distribution of tubes, and the overall heat transfer coefficient between the primary and the secondary side are the same as in the reference system. On the secondary side the coolant temperature, pressure, and the steam to water volume ratio are kept. Geometry of PMK-2 SG model is somewhat different from the full scale SG. Therefore, a question can arise how well SG model in PMK-2 can model SG in the plant. Test results of different transients, especially PHSTC and OAH-C2 tests dedicated to SG heat transfer study, show that SG behaviour in the plant can be reproduced well enough.

Cold and hot legs are volume scaled, and care was taken to reproduce the correct elevations of the loop seals in both the hot and cold legs. For practical reasons the lengths could not be maintained $1: 1$; therefore, a relatively large tube diameter of $46 \mathrm{~mm}$ has been chosen to keep the Froude number which is important to get stratification in two-phase natural circulation. The hot leg with the pressuriser surge line is presented in Figure 4.

The component models discussed above have about the same vertical position in the loop as the components of the primary circuit in the reference system. The main circulating pump is applied to produce the nominal operating flow conditions and flow coast down following pump trip in the transient process. For the pressuriser the volume scaling, the water to steam volume ratio, and the elevation of the water level are kept; however, the diameter and height ratios cannot be realized. For the hydroaccumulators the volume scaling and elevation are kept with $\mathrm{N}_{2}$ pressure upon the water level as in the plant.

Figure 5 shows the scheme of the PMK-2 facility. After the pump trip the pump is valved off by closing valves

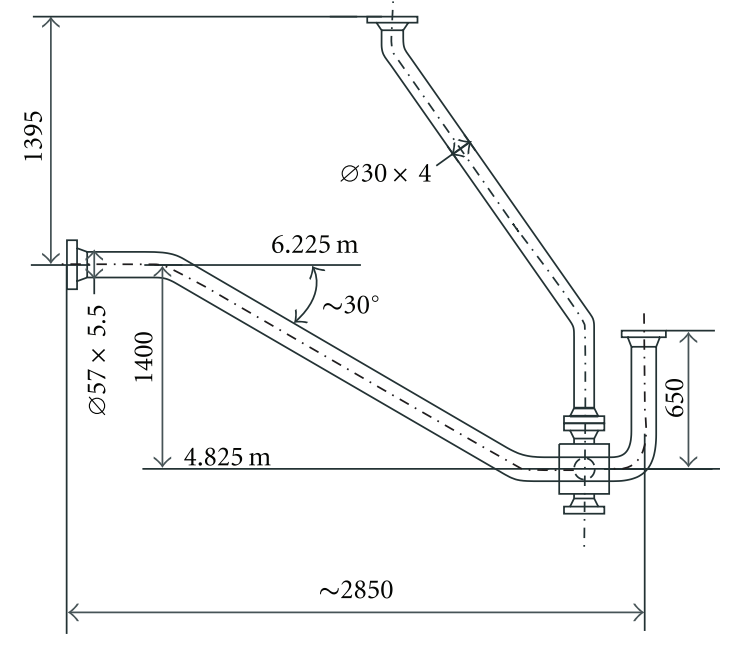

FIgURE 4: Hot leg with pressuriser surge line.

PV11 and MV12, while MV11 is open. From the emergency core cooling systems (ECCS) the four SITs of the Paks NPP are modelled by two vessels, and they are connected to the downcomer and upper plenum. The HP and LPI systems are modelled by the use of piston pumps. Figure shows locations of measured parameters, for example, PR21, TE15, LE11, LV21, and so forth, and the elevations of component models. The reference level of $0.0 \mathrm{~m}$ is the lower flat of the reactor model.

The nominal parameters of the PMK-2 corresponding to the nominal operating parameters of the reference plant are as follows: primary pressure: $12.3 \mathrm{MPa}$; coolant temperature at core inlet: $540 \mathrm{~K}$; core power: $664 \mathrm{~kW}$; mass flow rate: $4.5 \mathrm{~kg} / \mathrm{s}$; secondary pressure: $4.6 \mathrm{MPa}$; feedwater temperature: $493 \mathrm{~K}$; steam mass flow rate: $0.36 \mathrm{~kg} / \mathrm{s}$; HPIS and LPIS flow: 0.014 and $0.042 \mathrm{~kg} / \mathrm{s}$, respectively, for each unit.

Measurement locations are presented in circles as follows: TE: temperature; PR: pressure; LE: (coolant) level; LV: local void. The local void is measured by needle-shaped conductivity probes. The sampling rate of the data acquisition system is $1 \mathrm{~s}$.

\section{The PMK-2 Experimental Data Base for VVER-440/213 Plants}

The PMK-2 data base, described in detail in [1], covers the list of design basis accidents analysed in the Safety Analysis Report of the Paks plant as well as practically all test types described in the OECD-VVER cross-reference matrices. It consists of 55 tests, which address and help to understand all the important aspects of plant system behaviour in accident conditions. These tests can be divided into five groups as follows: 15 tests with $7.4 \%$ cold leg breaks; 10 tests with cold leg breaks of different sizes, covering a range from $0.5 \%$ to $30 \%$; 10 tests with hot leg breaks and primary to secondary leaks; 10 tests for natural circulation; 10 tests for plant transients and accidents. 


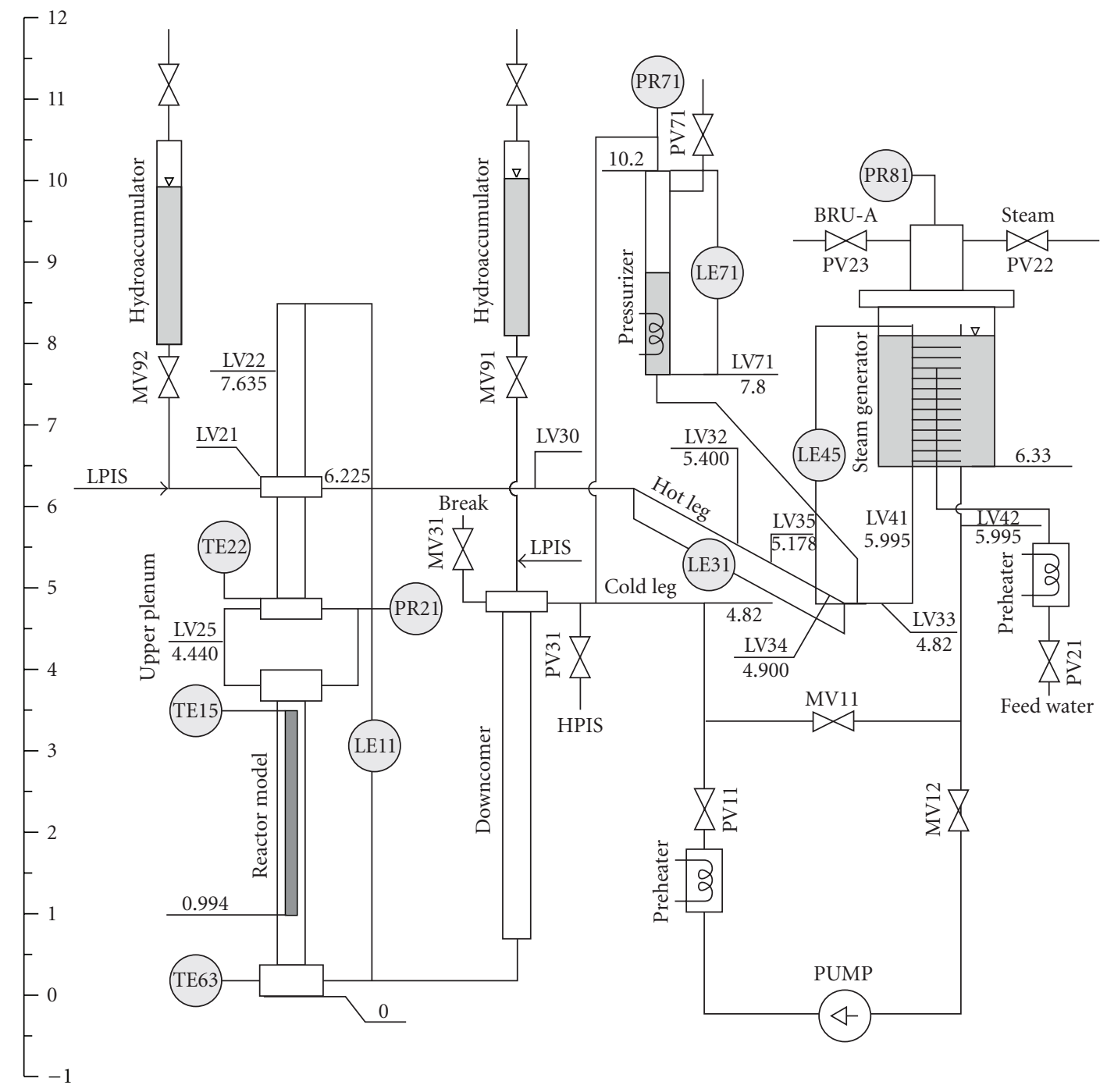

FIGURE 5: Scheme of PMK-2 facility.

The experimental results are available in digital form on a CD attached to [1].

A complete list of tests is given in Tables 1, 2, 3, 4, and 5.

\section{Major Findings of Experiments}

The significance of the PMK-2 experiments mainly consists in the creation of a unique, high-quality data base that can be used for code validation, especially for VVER-specific phenomena [3]. The OECD-VVER code validation matrices [5] for the three main groups of transients, namely, large breaks, small/intermediate leaks, and plant transients have been carefully reviewed with respect to what extent the PMK-2 tests represent thermohydraulic phenomena listed there. It was found that the following phenomena are simulated at a level required by the validation matrices: break flow; pressuriser thermohydraulics and surge line hydraulics; heat transfer in SG primary and secondary sides; single- and two-phase natural circulation; mixing and condensation during in- jection from ECCSs; loop seal behaviour in hot leg and clearance in cold leg; core heat transfer including DNB and dryout.

Besides addressing typical phenomena during transients, an important number of PMK-2 experiments support specific cases of plant performance, like operator actions taken in Emergency Operating Procedures and steam generator tube and header ruptures, system behaviour in a LOCA occurring during plant cooldown, and in an ATWS sequence. These data helped to validate codes for VVER-specific design basis accidents or for beyond design conditions.

Tests addressing the Emergency Operating Procedures of the Paks plant supported the following procedure developments: response to inadequate core cooling, response to degraded core cooling, post-LOCA cooldown and depressurisation, and response to loss of secondary heat sink and of loss of all AC power. The results experimentally supported the qualification of procedures and validation of codes. 
TABLE 1: 7,4\% cold leg breaks.

\begin{tabular}{|c|c|c|c|c|}
\hline $\begin{array}{l}\text { No. of } \\
\text { tests }\end{array}$ & $\begin{array}{c}\text { Project } \\
\text { identification }\end{array}$ & Test acronym & $\begin{array}{l}\text { Date of } \\
\text { tests }\end{array}$ & ECCS configuration and/or main objectives \\
\hline (1) & IAEA-SPE & SPE-1 & 1986 & Minimum ECCS configuration: 0 SIT and 1 HPIS \\
\hline (2) & ATKP-2 & SPE-ROV & 1987 & Without ECCS: 0 SIT, 0 HPIS and 0 LPIS, onset of core dryout \\
\hline (3) & ATKP-2 & $\mathrm{PAV}-\mathrm{CM}$ & 1987 & DBA case with ECCS configuration: 3 SITs and 1 HPIS, late SIT actuation \\
\hline$(4)$ & IAEA-SPE & SPE-2 & 1987 & $\begin{array}{l}\text { DBA case with ECCS configuration: } 3 \text { SITs and } 1 \text { HPIS, nominal initial power, } \\
\text { and delayed steam dump }\end{array}$ \\
\hline (5) & OKKFT G-11 & SP0 & 1988 & DBA case with ECCS configuration: 3 SITs and 1 HPIS, HL/CL connection \\
\hline (6) & OMFB 00307/91 & OM1-BF & 1992 & ECCS configuration: 3 SITs, 0 HPIS, 1 LPIS \\
\hline (7) & OMFB 00307/91 & OM1-G0 & 1992 & $\begin{array}{l}\text { DBA case with ECCS configuration: } 3 \text { SITs and } 0 \text { HPIS } \\
\text { AM actions, reference case, secondary bleed and feed }\end{array}$ \\
\hline (8) & OMFB 00307/91 & OM1-G1 & 1992 & $\begin{array}{l}\text { DBA case with ECCS configuration: } 3 \text { SITs and } 0 \text { HPIS } \\
\text { AM actions, noncondensables, secondary bleed and feed }\end{array}$ \\
\hline (9) & OMFB 00307/91 & OM1-G2 & 1992 & $\begin{array}{l}\text { DBA case with ECCS configuration: } 3 \text { SITs, } 0 \text { HPIS, } 1 \text { LPIS } \\
\text { AM actions, noncondensables, secondary bleed and feed }\end{array}$ \\
\hline (10) & IAEA-SPE & SPE-4 & 1993 & $\begin{array}{l}\text { DBA case with ECCS configuration: } 3 \text { SITs, } 0 \text { HPIS, } 1 \text { LPIS } \\
\text { AM actions, secondary bleed and feed }\end{array}$ \\
\hline$(11)$ & PHARE SRR3/95 & PHS-BF & 1999 & $\begin{array}{l}\text { DBA case with ECCS configuration: } 3 \text { SITs, } 0 \text { HPIS, } 1 \text { LPIS } \\
\text { AM actions, primary and secondary bleed and feed }\end{array}$ \\
\hline$(12)$ & IMPAM-VVER & IMP-21 & 2003 & $\begin{array}{l}\text { ECCS configuration: } 0 \text { HPIS, } 3 \text { SITs, } 1 \text { LPIS } \\
\text { AM actions: primary bleed and feed, with low pressuriser level }\end{array}$ \\
\hline (13) & IMPAM-VVER & IMP-22 & 2004 & $\begin{array}{l}\text { ECCS configuration, } 0 \text { HPIS, } 3 \text { SITs, } 1 \text { LPIS } \\
\text { AM actions: primary bleed and feed, early actuation }\end{array}$ \\
\hline (14) & IMPAM-VVER & IMP-23 & 2004 & $\begin{array}{l}\text { ECCS configuration, } 0 \text { HPIS, } 3 \text { SITs, } 1 \text { LPIS } \\
\text { AM actions: primary bleed and feed, a counterpart test to PACTEL, low SIT } \\
\text { pressure }\end{array}$ \\
\hline$(15)$ & IMPAM-VVER & IMP-32 & 2004 & $\begin{array}{l}\text { ECCS configuration: } 0 \text { HPIS, } 3 \text { SITs, } 1 \text { LPIS } \\
\text { AM actions: primary bleed and feed, a counterpart test to PACTEL }\end{array}$ \\
\hline
\end{tabular}

TABLE 2: Cold leg breaks of different sizes.

\begin{tabular}{|c|c|c|c|c|c|}
\hline $\begin{array}{l}\text { No. of } \\
\text { tests }\end{array}$ & $\begin{array}{c}\text { Project } \\
\text { identification }\end{array}$ & Test acronym & $\begin{array}{c}\text { Date of } \\
\text { tests }\end{array}$ & $\begin{array}{l}\text { Break size } \\
\%\end{array}$ & ECCS configuration and/or main objectives \\
\hline (1) & OKKFT G-11 & G11-35 & 1989 & 3.5 & Minimum ECCS configuration: 0 SIT, 1 HPIS \\
\hline (2) & OKKFT G-11 & CLB-14A & 1990 & 14.8 & $\begin{array}{l}\text { Minimum ECCS configuration: } 0 \text { SIT, } 1 \text { HPIS } \\
\text { Core dryout, cladding temperature excursion and cooldown }\end{array}$ \\
\hline (3) & OKKFT G-11 & CLB-14B & 1990 & 14.8 & $\begin{array}{l}\text { DBA case with ECCS configuration: } 3 \text { SITs and } 1 \text { HPIS } \\
\text { Core dryout, cladding temperature excursion and cooldown }\end{array}$ \\
\hline (4) & OKKFT G-11 & CLB-10A & 1990 & 1.0 & $\begin{array}{l}\text { Minimum ECCS configuration: } 0 \text { SIT, } 1 \text { HPIS } \\
\text { Test with a classical SBLOCA break size }\end{array}$ \\
\hline (5) & AEKI & CLB-10B & 1994 & 1.0 & $\begin{array}{l}\text { Minimum ECCS configuration: } 0 \text { SIT, } 1 \text { HPIS } \\
\text { Test of } 1990(1 \% \text { CLB }) \text { is repeated with local void probes }\end{array}$ \\
\hline (6) & OMFB 0881/95 & OM5-BF & 1995 & 1.0 & $\begin{array}{l}\text { Minimum ECCS configuration: } 0 \text { SIT, } 1 \text { HPIS } \\
\text { AM actions, primary bleed and feed }\end{array}$ \\
\hline (7) & PHARE SRR3/95 & PHS-05 & 1999 & 0.5 & $\begin{array}{l}\text { ECCS configuration: } 0 \text { SIT, } 3 \text { HPISs } \\
\text { Overfeeding by high pressure injection }\end{array}$ \\
\hline (8) & OAH-CAMP & $\mathrm{OAH}-\mathrm{C} 1$ & 1999 & 2.0 & $\begin{array}{l}\text { ECCS configuration: } 2 \text { SITs, } 0 \text { HPIS } \\
\text { AM actions, secondary bleed and feed }\end{array}$ \\
\hline (9) & IMPAM-VVER & IMP-1 & 2003 & 0.5 & $\begin{array}{l}\text { ECCS configuration: } 3 \text { HPIS, } 0 \text { SIT } \\
\text { Post-LOCA cooldown, modelling ES- } 1.2 \text { procedure in Paks NPP }\end{array}$ \\
\hline$(10)$ & IMPAM-VVER & IMP-31 & 2004 & 30 & $\begin{array}{l}\text { ECCS configuration: } 0 \text { HPIS, } 0 \text { SIT, } 1 \text { LPIS } \\
\text { LBLOCA during cooldown }\end{array}$ \\
\hline
\end{tabular}


TABLE 3: Hot leg breaks and primary to secondary leaks.

\begin{tabular}{|c|c|c|c|c|c|}
\hline $\begin{array}{l}\text { No. of } \\
\text { tests }\end{array}$ & $\begin{array}{c}\text { Project } \\
\text { identification }\end{array}$ & Test acronym & $\begin{array}{l}\text { Date of } \\
\text { tests }\end{array}$ & $\begin{array}{l}\text { Break size } \\
\quad \%\end{array}$ & ECCS configuration and/or main objectives \\
\hline (1) & OKKFT G-11 & G11-7A & 1989 & 7.4 & $\begin{array}{l}\text { ECCS configuration: } 0 \text { SIT and } 1 \text { HPIS } \\
\text { Hot leg break LOCA for comparison }\end{array}$ \\
\hline (2) & OKKFT G-11 & G11-7B & 1989 & 7.4 & $\begin{array}{l}\text { DBA case with ECCS configuration: } 3 \text { SITs and } 1 \text { HPIS } \\
\text { Hot leg break LOCA for comparison }\end{array}$ \\
\hline (3) & OKKFT G-11 & G11-PS & 1988 & 4.7 & $\begin{array}{l}\text { DBA case with ECCS configuration: } 3 \text { SITs and } 2 \text { HPISs } \\
\text { Study of system behaviour in PRISE conditions }\end{array}$ \\
\hline (4) & IAEA-SPE & SPE-3 & 1989 & 11.8 & $\begin{array}{l}\text { DBA case with ECCS configuration: } 3 \text { SITs and } 3 \text { HPISs } \\
\text { PRISE, SG safety valve remains open }\end{array}$ \\
\hline (5) & PHARE 4.2.6b & PH4-PS & 1996 & 1.0 & $\begin{array}{l}\text { DBA case with minimum ECCS configuration: } 2 \text { SITs and } 1 \text { HPIS } \\
\text { Pressuriser thermohydraulics when safety valve opens }\end{array}$ \\
\hline (6) & PHARE 4.2.6b & PH4-SLB & 1997 & 32.0 & $\begin{array}{l}\text { DBA case with minimum ECCS configuration: } 2 \text { SITs, } 1 \text { HPIS, } 1 \text { LPIS } \\
\text { Pressuriser surge line break, core dryout, refill, reflood }\end{array}$ \\
\hline (7) & PHARE 2.02 & PH2-PS & 1997 & 4.5 & $\begin{array}{l}\text { Maximum ECCS configuration: } 4 \text { SITs and } 3 \text { HPISs } \\
\text { PRISE, SG safety valve stuck open, spray in PRZ, sec. bleed and feed }\end{array}$ \\
\hline (8) & PHARE VVER01 & PHV-11 & 1998 & 4.5 & $\begin{array}{l}\text { ECCS configuration: } 2 \text { SITs and } 2 \text { HPISs } \\
\text { PRISE, AM actions, spray in PRZ, secondary bleed and feed }\end{array}$ \\
\hline (9) & PHARE VVER01 & PHV-12 & 1998 & 1.5 & $\begin{array}{l}\text { ECCS configuration: } 2 \text { SITs and } 2 \text { HPISs } \\
\text { PRISE, AM actions, spray in PRZ, secondary bleed and feed }\end{array}$ \\
\hline (10) & PHARE VVER01 & PHV-13 & 1998 & 0.7 & $\begin{array}{l}\text { ECCS configuration: } 1 \text { HPIS and no SITs } \\
\text { PRISE, AM actions, spray in PRZ, secondary bleed and feed }\end{array}$ \\
\hline
\end{tabular}

Note: There are three types of breaks:

(i) hot leg break in tests no. 1 and 2,

(ii) leak on the pressuriser in tests no. 5 and 6,

(iii) primary to secondary leaks in tests nos. 3, 4, 7, 8, 9, and 10.

TABLE 4: Tests for natural circulation.

\begin{tabular}{|c|c|c|c|c|}
\hline $\begin{array}{l}\text { No. of } \\
\text { tests }\end{array}$ & $\begin{array}{l}\text { Project } \\
\text { identification }\end{array}$ & Test acronym & $\begin{array}{c}\text { Date of } \\
\text { tests }\end{array}$ & Main objectives \\
\hline (1) & OKKFT G-11 & G11-TC & 1988 & $\begin{array}{l}\text { Study of natural circulation, step by step decrease of primary inventory } \\
\text { up to crisis }\end{array}$ \\
\hline (2) & OMFB 00307/91 & OM1-TC & 1993 & $\begin{array}{l}\text { One- and two-phase natural circulation, step by step coolant decrease, } \\
\mathrm{N}_{2} \text { in the system, crisis }\end{array}$ \\
\hline (3) & PA Rt. & PAV-GFK & 1993 & Study of disturbances: shut-down conditions, $\mathrm{N}_{2}$ in the upper plenum \\
\hline (4) & PA Rt. & PAV-FET & 1993 & Study of disturbances: closing of main isolation valve \\
\hline (5) & PA Rt. & PAV-GKK & 1993 & Study of disturbances: gas in the SG collectors \\
\hline (6) & PA Rt. & PAV-HVM & 1993 & Study of disturbances: cold water injection to the hot leg \\
\hline (7) & OMFB, 1044/96 & OM6-GFK & 1998 & Effect of gas injection to the upper plenum \\
\hline (8) & OMFB, 1044/96 & OM6-FET & 1998 & Effect of isolation valve closing in the cold leg \\
\hline (9) & PHARE SRR3/95 & PHS-TC & 1998 & SG heat transfer study with level decrease, step by step \\
\hline$(10)$ & OAH-CAMP & $\mathrm{OAH}-\mathrm{C} 2$ & 2001 & $\begin{array}{l}\text { SG heat transfer study with continuous coolant level decrease in the SG } \\
\text { secondary side }\end{array}$ \\
\hline
\end{tabular}

In the field of primary to secondary leaks the tests are representative for plant response in these VVER-specific accident types and reflect the effectiveness of secondary bleed and feed and of pressure reduction by pressuriser spray and supported the development of effective operator actions to minimize the coolant loss to the atmosphere.

The test investigating the consequences of a LOCA occurring during plant cooldown, when the pressuriser is filled by nitrogen, supplied information on spreading of noncondensable gas along the primary circuit following the cold leg break.
An example on core heat transfer including DNB and dryout. The safety significance of these phenomena is the control of the cladding temperature. The core heat transfer is the first step when the heat is transferred from the fuel surface to the coolant; then the steam generator tubes transmit the heat to the secondary side. In the case of large breaks all heat transfer regimes from single phase liquid to single phase (saturated and superheated) steam are relevant, but cladding temperatures are mainly influenced by correct prediction of critical heat flux, heat transfer to steam, precooling by entrained liquid during reflooding and rewetting. The cladding 
TABle 5: Plant transients and accidents.

\begin{tabular}{|c|c|c|c|c|}
\hline $\begin{array}{l}\text { No. of } \\
\text { tests }\end{array}$ & $\begin{array}{c}\text { Project } \\
\text { identification }\end{array}$ & Test acronym & $\begin{array}{l}\text { Date of } \\
\text { tests }\end{array}$ & Main objectives \\
\hline (1) & AEKI & LOF-66 & 1986 & $\begin{array}{l}\text { Study of system behaviour in total loss of flow, minimum value of } \\
\text { DNBR }\end{array}$ \\
\hline (2) & ATKP & ATK-PC & 1987 & $\mathrm{MCP}$ rotor seizure, minimum DNBR ratio \\
\hline (3) & ATKP & ATK-FW & 1987 & $\begin{array}{l}\text { Total loss of feedwater, experimental support to system analysis in } \\
\text { Paks NPP }\end{array}$ \\
\hline (4) & OMFB 00307/91 & OM1-FW & 1992 & $\begin{array}{l}\text { Total loss of feedwater, effect of secondary bleed with passive } \\
\text { secondary feed }\end{array}$ \\
\hline (5) & OMFB 00307/91 & OM1-ST & 1992 & Station blackout, effectiveness of secondary bleed and feed \\
\hline (6) & OMFB 00307/91 & OM1-MSH & 1993 & Main steam header break, secondary bleed and feed \\
\hline (7) & OMFB 00881/95 & OM5-FW & 1996 & Total loss of feedwater, secondary bleed, and primary bleed and feed \\
\hline (8) & OMFB 00881/95 & OM5-ST & 1997 & Station blackout, secondary bleed, and primary bleed and feed \\
\hline (9) & PHARE VVER02 & PHV-21 & 1999 & $\begin{array}{l}\text { Station blackout with ATWS, density, and boron concentration } \\
\text { feedback }\end{array}$ \\
\hline (10) & PHARE VVER02 & PHV-22 & 1999 & $\begin{array}{l}\text { Station blackout with ATWS, density, and boron concentration } \\
\text { feedback }\end{array}$ \\
\hline
\end{tabular}

temperatures measured in PMK-2 allow identifying these regimes. The limitations for this phenomenon are in the 1$\mathrm{D}$ representation of the core and the uniform axial power profile.

Quality of measurements strongly depends on the accuracy of measured parameters. In the PMK-2 tests, measurement transducers of temperatures, pressures, differential pressures, levels, local voids, and flow rates are calibrated in accordance with the measurement quality control system. Accuracy estimation includes a calibration constant, absolute maximum error, and standard deviation. In addition, there is a calibration system, and an in-site calibration before each test can be made together with mass and energy balance measurement at operation conditions [1]. lows:

Experiments selected to represent phenomena are as fol-

(i) OAH-C1, 2\% cold leg break without HPIS, with secondary bleed,

(ii) PHS-BF, 7.4\% cold leg break with secondary side bleed and primary side bleed and feed,

(iii) PH4-SLB, 32\% break in the surge line at the hot leg connection.

Figure 6 presents the core model with thermocouples to identify thermocouple locations on different rods (from 1 to 19) and at different levels. The identification is given in Table 6 with thermocouples TE10 to TE19, number of rods, where temperatures are measured, and the level from $0.0 \mathrm{~m}$ elevation.

Tables 7 and 8 present the heater rod surface temperatures in OAH-C1 and in PHS-05, PHS-BF, and PH4-SLB, respectively. Table 8 includes data from PHS-05 test to show similar results for the test case having the smallest break size in the PMK-2 tests. Table 7 includes cladding temperatures measured at elevations of 2.994 and $3.444 \mathrm{~m}$ as follows: TE14 is on rod no. 6 in normal location typical for bundles; TE15 is on rod no. 11 in wall location, TE16 is on rod no. 1 in central
TABle 6: Thermocouple locations in the core model (see Figure 6), measuring cladding temperatures in different rods and elevations.

\begin{tabular}{lccc}
\hline Identification & $\begin{array}{c}\text { Number of } \\
\text { rods }\end{array}$ & $\begin{array}{c}\text { Level from } \\
0.00 \mathrm{~m}, \mathrm{~m}\end{array}$ & $\begin{array}{c}\text { Levels from core } \\
\text { inlet, mm }\end{array}$ \\
\hline TE10 & 10 & 1.044 & 50 \\
TE11 & 2 & 1.494 & 500 \\
TE12 & 8 & 1.994 & 1000 \\
TE13 & 9 & 2.494 & 1500 \\
TE14 & 6 & 2.994 & 2000 \\
TE15 & 11 & 3.444 & 2450 \\
TE16 & 1 & 3.444 & 2450 \\
TE17 & 16 & 3.444 & 2450 \\
TE18 & 2 & 3.444 & 2450 \\
TE19 & 3 & 3.444 & 2450 \\
\hline
\end{tabular}

location, TE17 is on rod no. 17 in corner location, TE18 and TE19 are on rod no. 2 and 3 in normal locations, respectively, (see also Figure 1). Column "Temperature excursion" shows starting time of temperature excursions (starts), the maximum value of cladding temperatures (max.), and the time when the temperature excursion is ended (end). The other columns are the transient time (Time, s), the coolant level in the reactor model (LE11), and the value of cladding temperatures. There are three maximum values of cladding temperatures (1., 2. and 3. max). These are the maximum temperatures in cases of dryout as it can be seen also in Figures 8, 9, and 10 .

The $\mathrm{OAH}-\mathrm{C} 1$ test is started from the nominal operating parameters of the plant, with the availability of 2 SITs only and with secondary side bleed. Injection from SITs begins at $159 \mathrm{~s}$ and terminates at $2548 \mathrm{~s}$. The secondary bleed is initiated at $1502 \mathrm{~s}$. Though the SIT injection starts at $159 \mathrm{~s}$, it practically stops due to the stagnation of the primary pressure, and it is reinitiated by the secondary bleed at $1502 \mathrm{~s}$. 


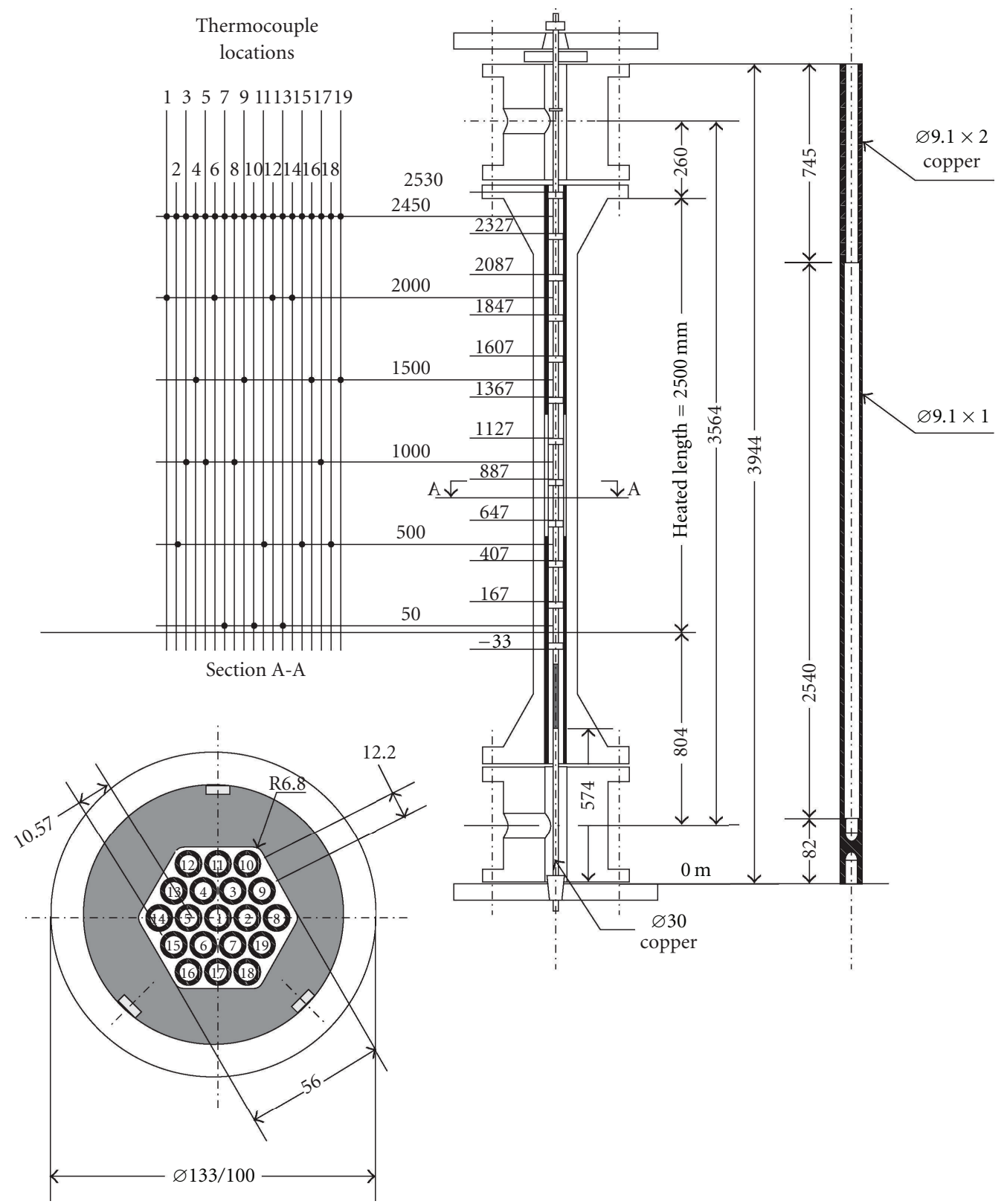

FIGURE 6: Core model with thermocouple locations for the identification of locations on rods and level (from [1]).

The cold water from the SITs is injected into saturated steam in the downcomer head, causing extensive direct contact condensation.

Results focusing on dryout occurrence in different regions of the core are presented in Table 7 and in Figures 7 to 10 . Crisis occurs first at the elevation of $2.994 \mathrm{~m}$, with the maximum value of TE14 temperature in rod no. 6 . It is $628 \mathrm{~K}$ at $1156 \mathrm{~s}$ and at a coolant level of $2.761 \mathrm{~m}$ in the reactor model (LE11). At the outlet section $(3.444 \mathrm{~m})$ crisis occurs three times in rod no. 11, 1, 16, 2, and 3, in wall position (TE15), central position (TE16), corner position (TE17), and in normal positions (TE18, TE19). The highest temperatures were measured during the third temperature excursion: 718.0 K (wall position), 739.2 K (central position), 713.2 (corner position), 737.7, and $742.0 \mathrm{~K}$ (normal positions). The effect of cold channel wall can be seen in the maximum temperatures.

The PHS-BF test is started from nominal operating parameters of the plant, with the availability of 3 SITs and 1 LPIS. To cool down the system, secondary side bleed is initiated at $900 \mathrm{~s}$. 2 SITs inject cold water to the downcomer and 1 SIT to the upper plenum from 43.0 to $693 \mathrm{~s}$.

Results obtained are shown in Table 8 and in Figures $11,12,13$, and 14. Crisis occurs at the three uppermost instrumented elevations $(2.494 \mathrm{~m}, 2.994 \mathrm{~m}$, and $3.444 \mathrm{~m})$. At the outlet level the crisis occurs in the same rods as in test $\mathrm{OAH}-\mathrm{C} 1$, but earlier in the transient, due to the faster transient process. 
TABLE 7: Cladding temperatures in OAH-C1 test.

\begin{tabular}{|c|c|c|c|c|c|}
\hline Identification & $\begin{array}{l}\text { Location rod no./elevation } \\
\qquad-1 \mathrm{~m}\end{array}$ & Temperature excursion & $\begin{array}{c}\text { Time } \\
\mathrm{s}\end{array}$ & $\begin{array}{c}\text { LE11 } \\
\mathrm{m}\end{array}$ & $\begin{array}{c}\text { Temperature } \\
\mathrm{K}\end{array}$ \\
\hline \multirow[t]{3}{*}{ TE14 } & $6 / 2.994$ & Starts & 1131 & 2.774 & 543.4 \\
\hline & normal & Max. & 1156 & 2.761 & 628.4 \\
\hline & & End & 1175 & 2.696 & 549.9 \\
\hline \multirow[t]{5}{*}{ TE15 } & $11 / 3.444$ & Starts & 1118 & 2.968 & 544.4 \\
\hline & wall & 1. $\max$. & 1180 & 3.232 & 684.0 \\
\hline & & 2. $\max$. & 1263 & 3.210 & 692.7 \\
\hline & & 3. $\max$. & 1515 & 2.970 & 718.0 \\
\hline & & End & 1585 & 2.874 & 546.0 \\
\hline \multirow[t]{5}{*}{ TE16 } & $1 / 3.444$ & Starts & 1119 & 2.947 & 544.7 \\
\hline & central & 1. $\max$. & 1179 & 3.144 & 697.0 \\
\hline & & 2. $\max$. & 1260 & 3.145 & 702.4 \\
\hline & & 3. $\max$. & 1515 & 2.970 & 739.2 \\
\hline & & End & 1592 & 3.141 & 546.0 \\
\hline \multirow[t]{5}{*}{ TE17 } & $16 / 3.444$ & Starts & 1115 & 3.021 & 544.4 \\
\hline & corner & 1. max. & 1179 & 3.144 & 680.7 \\
\hline & & 2. $\max$ & 1259 & 3.068 & 681.7 \\
\hline & & 3. $\max$. & 1514 & 2.886 & 713.2 \\
\hline & & End & 1585 & 2.874 & 546.0 \\
\hline \multirow[t]{5}{*}{ TE18 } & $2 / 3.444$ & Starts & 1117 & 2.985 & 544.4 \\
\hline & normal & 1. $\max$. & 1180 & 3.232 & 701.0 \\
\hline & & 2. $\max$. & 1261 & 3.184 & 708.7 \\
\hline & & 3. $\max$. & 1515 & 2.970 & 737.7 \\
\hline & & End & 1590 & 3.006 & 546.0 \\
\hline \multirow[t]{5}{*}{ TE19 } & $3 / 3.444$ & Starts & 1117 & 2.985 & 544.4 \\
\hline & normal & 1. $\max$ & 1179 & 3.144 & 711.0 \\
\hline & & 2. $\max$ & 1261 & 3.145 & 712.4 \\
\hline & & 3. $\max$ & 1514 & 2.886 & 742.0 \\
\hline & & end & 1555 & 3.007 & 546.0 \\
\hline
\end{tabular}

The PH4-SLB test is started from the nominal operating parameters of the plant, with ECCS configuration as 2 SITs, 1 HPIS, and 1 LPIS. 2 SITs inject cold water to the upper plenum. The reactor model is almost fully empty in the time interval of 220 to $350 \mathrm{~s}$. The HPIS injection begins at $17.0 \mathrm{~s}$, the SIT injection starts at $20 \mathrm{~s}$, while LPIS flow is initiated at 304 s.

Results obtained are shown in Table 8 and in Figures 15, 16,17 , and 18. Crisis occurs at elevations and rods as in the case of PHS-BF test but, due to the large break size, earlier in time and with higher peak temperature. The maximum temperature is $943.6 \mathrm{~K}$ in rod no. 1, that is, in the central rod at the outlet level.

\section{PMK-2 Test Results in International Code Validation}

PMK-2 test results have been continuously applied to the validation of different versions of the ATHLET, CATHARE, and RELAP5 codes, since the first IAEA code validation exercise in 1986. In addition, PMK-2 tests figure in the matrices of developmental assessment of internationally recognised computer codes for safety analysis, like ATHLET and RELAP5.

Three small break LOCA and one primary to secondary leak tests served as a basis for VVER-specific Standard Problem Exercises organised under the umbrella of IAEA in the period 1987 to 1995 [6-9].

A special small break LOCA test was run to investigate the hot leg loop seal behaviour and the effectiveness of secondary side bleed, with the aim to support code validation activities within the US NRC CAMP programme [10].

A large number of tests were conducted in EU-PHARE and EU-Framework programmes covering a wide variety of test types including pressuriser surge line break, large primary to secondary leakage, station blackout with ATWS, and tests supporting accident management strategies in VVER-440/213 plants [3]. 


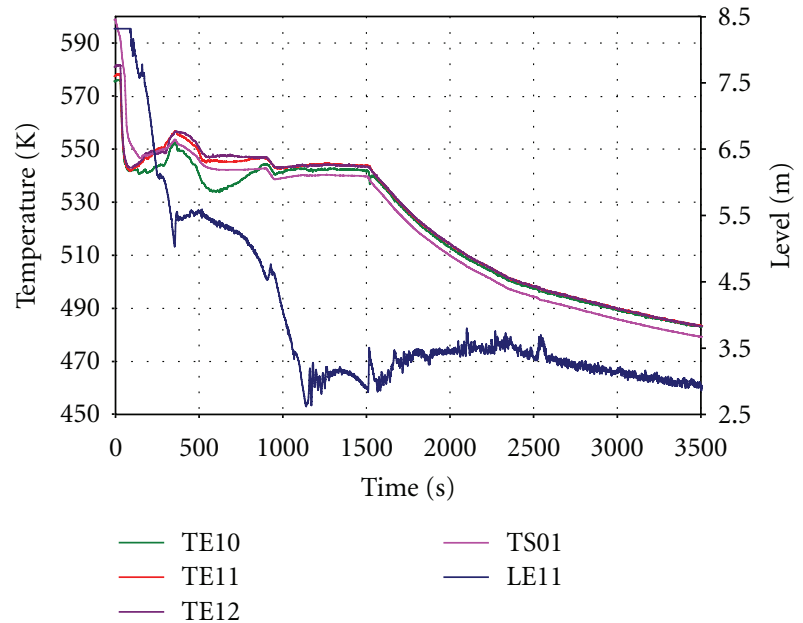

FIgure 7: Cladding temperatures TE10, TE11, TE12, saturation temperature (TS01) and coolant collapsed level in the core model (LE11), in OAH-C1, 2\% cold leg break without HPIS, with secondary bleed.

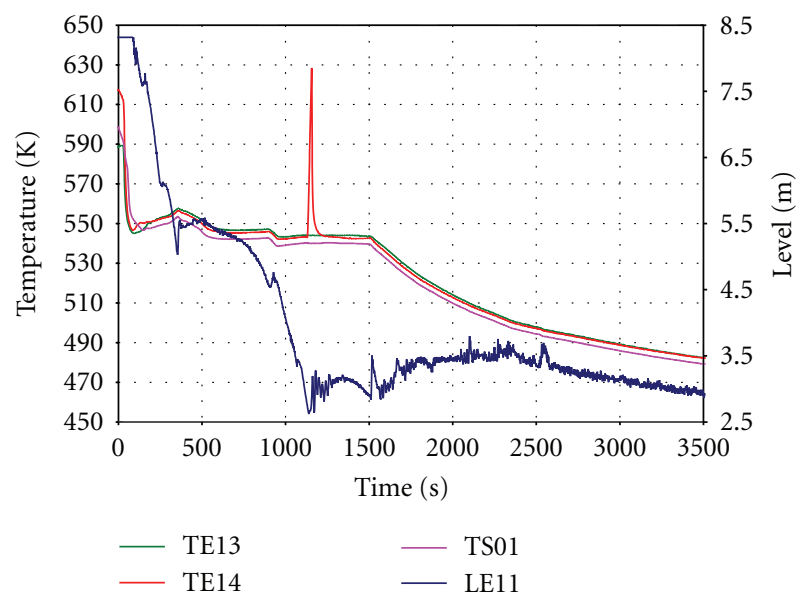

FIGURE 8: Cladding temperatures TE13, TE14, saturation temperature (TS01) and coolant collapsed level in the core model (LE11), in OAH-C1, 2\% cold leg break without HPIS, with secondary bleed.

Twenty-eight PMK-2 tests were applied to different international code validation exercises, and several versions of ATHLET, CATHARE, and RELAP5 have been assessed by foreign and Hungarian experts. The expertise gained in international cooperations-involving experts of 29 countries participating in PMK-2 projects-helped to better understand VVER system behaviour and reach a high level of modelling of accident sequences. Results of these activities are referenced in $[1,3]$, together with validation results obtained in national projects.

\section{Results of Validation of ATHLET, CATHARE, and RELAP5}

Since codes applied for safety analysis in Hungary are ATHLET for large break LOCA, RELAP5 for small break LOCA

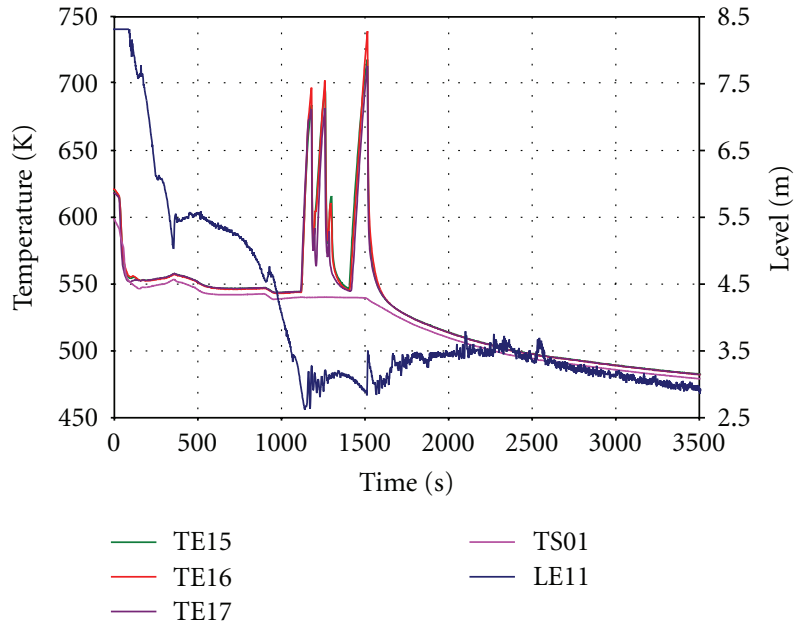

FIgure 9: Cladding temperature TE15, TE16, TE17, saturation temperature (TS01) and coolant collapsed level in the core model (LE11), in OAH-C1, 2\% cold leg break without HPIS, with secondary bleed.

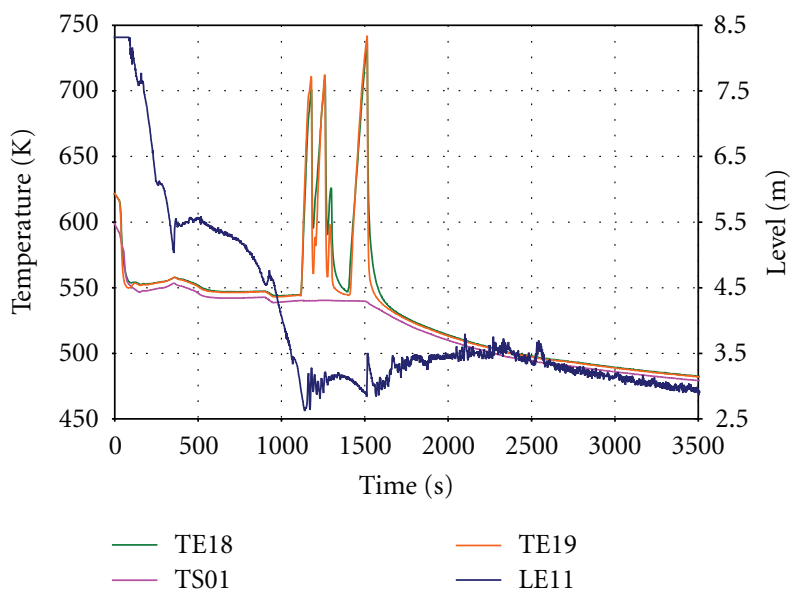

FIgURE 10: Cladding temperatures TE18, TE19, saturation temperature (TS01) and coolant collapsed level in the core model (LE11), in OAH-C1, 2\% cold leg break without HPIS, with secondary bleed.

and plant transient analyses, as well as CATHARE, which is used as an independent tool in support of the regulatory authority, validation activity in the country concentrated on these codes [3].

Methodologies of code validation used in PMK-2 projects include both qualitative and quantitative assessments. The former was almost exclusively applied in the early phase of code validation by integral experiments. It is based on visual observation and engineering judgement of the agreement. Also the quantitative assessment methodology includes a qualitative part, which is a prerequisite to the quantitative part. Quantitative assessment results were obtained by the Fast Fourier Transform Based Method, which had extensively been used also in OECD and IAEA standard problems [11-13]. 
TABLE 8: Cladding temperatures in PHS-05, PHS-BF, and PH4-SLB tests.

\begin{tabular}{|c|c|c|c|c|c|c|c|}
\hline \multirow[t]{2}{*}{ Identification } & \multirow{2}{*}{$\begin{array}{l}\text { Location rod. no./elevation } \\
\qquad-1 \mathrm{~m}\end{array}$} & \multicolumn{2}{|c|}{$\begin{array}{c}\text { PHS-05 } \\
\text { Break size } 0.5 \%\end{array}$} & \multicolumn{2}{|c|}{$\begin{array}{c}\text { PHS-BF } \\
\text { Break size } 7.4 \%\end{array}$} & \multicolumn{2}{|c|}{$\begin{array}{c}\text { PH4-SLB } \\
\text { Break size 32\% }\end{array}$} \\
\hline & & $\begin{array}{c}\text { Time } \\
\mathrm{s}\end{array}$ & $\begin{array}{c}\text { Temp. } \\
\mathrm{K}\end{array}$ & $\begin{array}{c}\text { Time } \\
\text { s }\end{array}$ & $\begin{array}{c}\text { Temp. } \\
\text { K }\end{array}$ & $\begin{array}{c}\text { Time } \\
\mathrm{s}\end{array}$ & $\begin{array}{c}\text { Temp. } \\
\mathrm{K}\end{array}$ \\
\hline \multirow[t]{3}{*}{ TE13 } & $9 / 2.494$ & - & - & 479 & 525.4 & 238 & 546.7 \\
\hline & wall & & & 717 & 543.4 & 406 & 851.4 \\
\hline & & & 1557 & 470.6 & & & \\
\hline \multirow[t]{3}{*}{ TE14 } & $6 / 2.994$ & - & - & 493 & 551.2 & 236 & 553.4 \\
\hline & normal & & & 733 & 564.4 & 419 & 927.8 \\
\hline & & & 1578 & 608.2 & & & \\
\hline \multirow[t]{3}{*}{ TE15 } & $11 / 3.444$ & 4768 & 603.4 & 525 & 586.7 & 224 & 501.2 \\
\hline & wall & & & 749 & 572.7 & 444 & 821.4 \\
\hline & & & 1603 & 685.7 & & & \\
\hline \multirow[t]{3}{*}{ TE16 } & $1 / 3.444$ & 4768 & 606.7 & 520 & 591.7 & 223 & 524.0 \\
\hline & central & & & 749 & 583.0 & 444 & 943.6 \\
\hline & & & 1603 & 725.2 & & & \\
\hline \multirow[t]{3}{*}{ TE17 } & $16 / 3.444$ & 4767 & 598.0 & 512 & 593.4 & 223 & 503.4 \\
\hline & corner & & & 748 & 586.4 & 440 & 882.0 \\
\hline & & & 1590 & 667.7 & & & \\
\hline \multirow[t]{3}{*}{ TE18 } & $2 / 3.444$ & 4768 & 609.7 & 525 & 598.4 & 224 & 512.0 \\
\hline & normal & & & 749 & 584.4 & 444 & 913.0 \\
\hline & & & 1609 & 725.4 & & & \\
\hline \multirow[t]{3}{*}{ TE19 } & $3 / 3.444$ & 4768 & 613.0 & 520 & 604.0 & 224 & 517.0 \\
\hline & normal & & & 749 & 591.4 & 435 & 916.0 \\
\hline & & & 1600 & 717.0 & & & \\
\hline
\end{tabular}

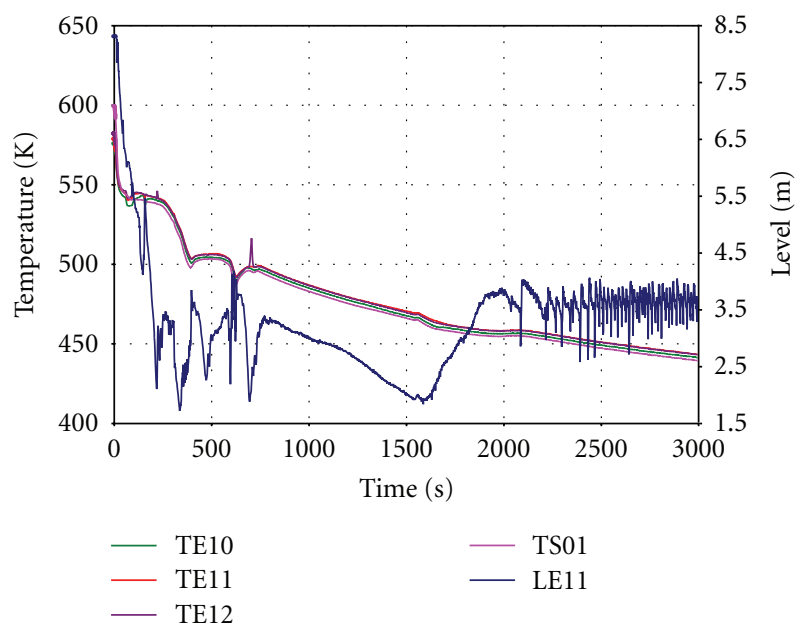

Figure 11: Cladding temperatures TE10, TE11, TE12, saturation temperature (TS01) and coolant collapsed level in the core model (LE11), in PHS-BF, 7.4\% cold leg break with secondary bleed and primary side bleed and feed.

Results of code validation work in the PMK-2 projects are presented by tests selected in a way to represent major test types of the OECD-VVER code validation matrices: different small break LOCAs, pressuriser leak, steam

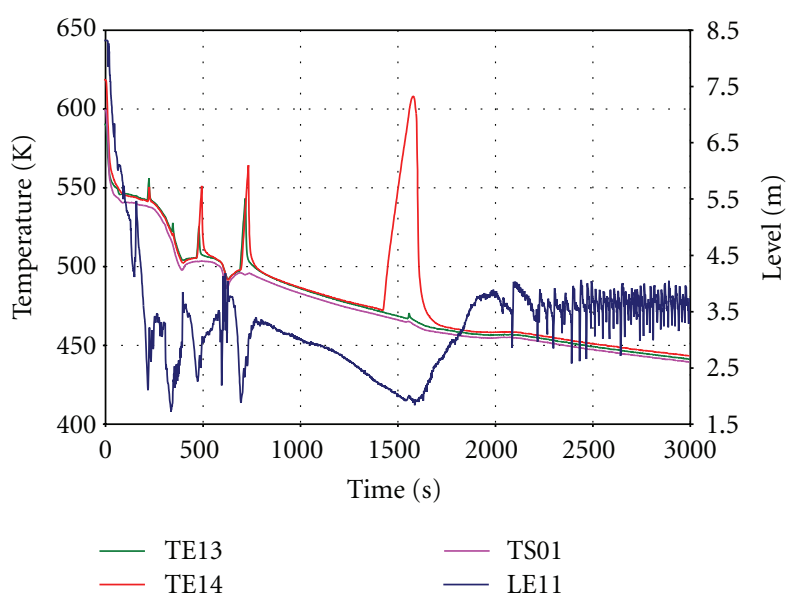

Figure 12: Cladding temperatures TE13, TE14, saturation temperature (TS01) and coolant collapsed level in the core model (LE11) in PHS-BF, 7.4\% cold leg break with secondary bleed and primary side bleed and feed.

generator header rupture, large break LOCA showing the three typical phases of blowdown, refill and reflood, and station blackout with ATWS. Results are as follows. 


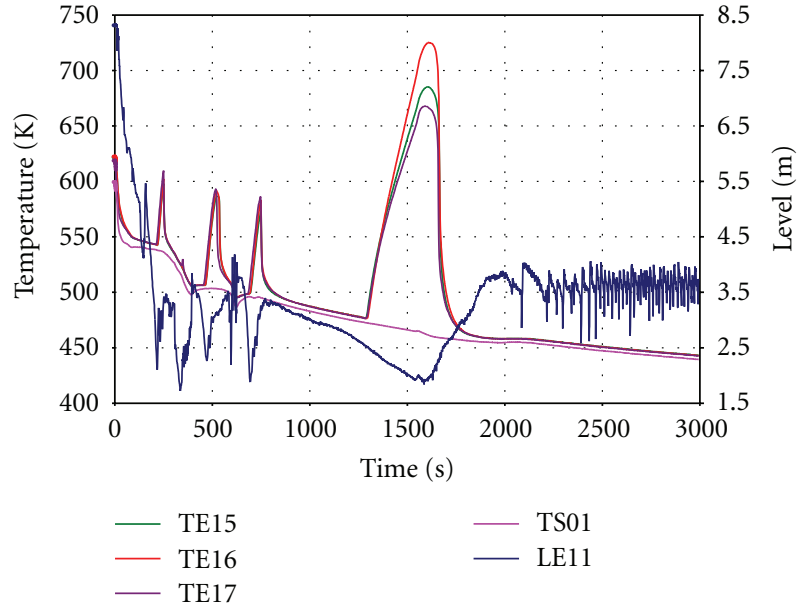

Figure 13: Cladding temperatures TE15, TE16, TE17, saturation temperature (TS01) and coolant collapsed level in the core model (LE11), in PHS-BF, 7.4\% cold leg break with secondary bleed and primary side bleed and feed.

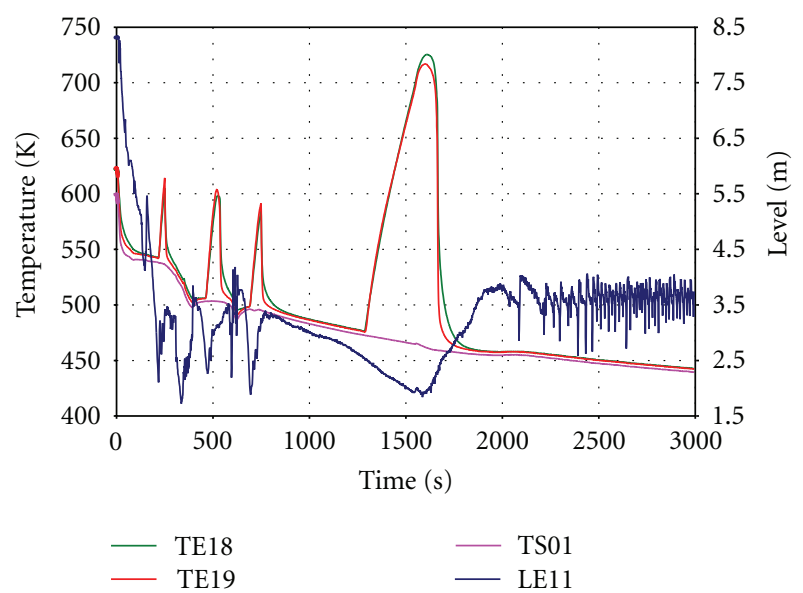

FIGURE 14: Cladding temperatures TE18, TE19, saturation temperature (TS01) and coolant collapsed level in the core model (LE11) in PHS-BF, 7.4\% cold leg break with secondary bleed and primary side bleed and feed.

For small break LOCA, all the three codes are capable of predicting the overall trend of transient and the testspecific phenomena in a "qualitatively correct" way with some quantitative disagreements. Results of the quantitative assessments gave "very good" qualification levels.

Results of the large break LOCA test calculated by the ATHLET code can be qualified to be qualitatively and quantitatively "correct". Results of quantitative assessments for CATHARE and RELAP5 give "very good" qualification level for both codes. In spite of these promising results the codes cannot be regarded as qualified for VVER large break cases, since the PMK-2 data base contains only tests, which lie in the lower part of the large LOCA break size.

The qualitative assessment of RELAP 5 by a plant transient station blackout with ATWS shows that predictions of key parameters and sequence of events are qualitatively and

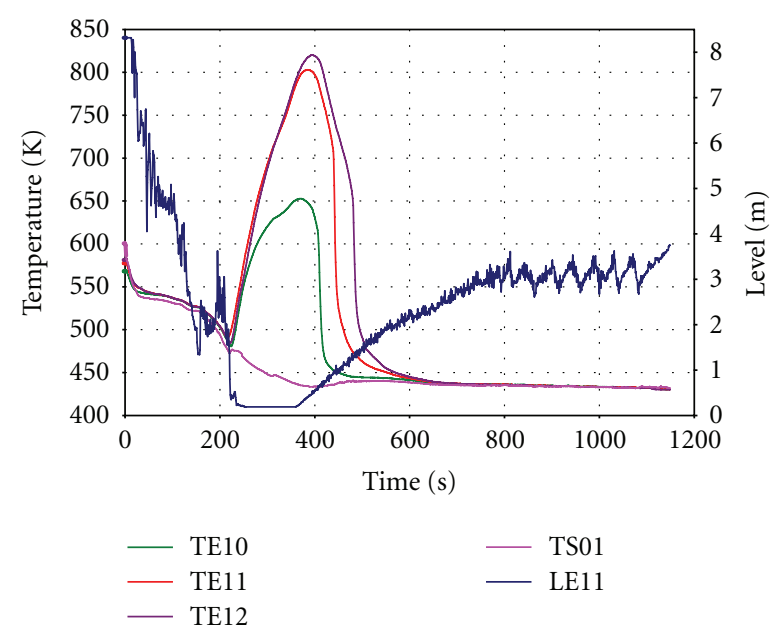

Figure 15: Cladding temperatures TE10, TE11, TE12, saturation temperature (TS01) and coolant collapsed level in the core model (LE11), in PH4-SLB, 32\% break in the surge line at the hot leg connection.

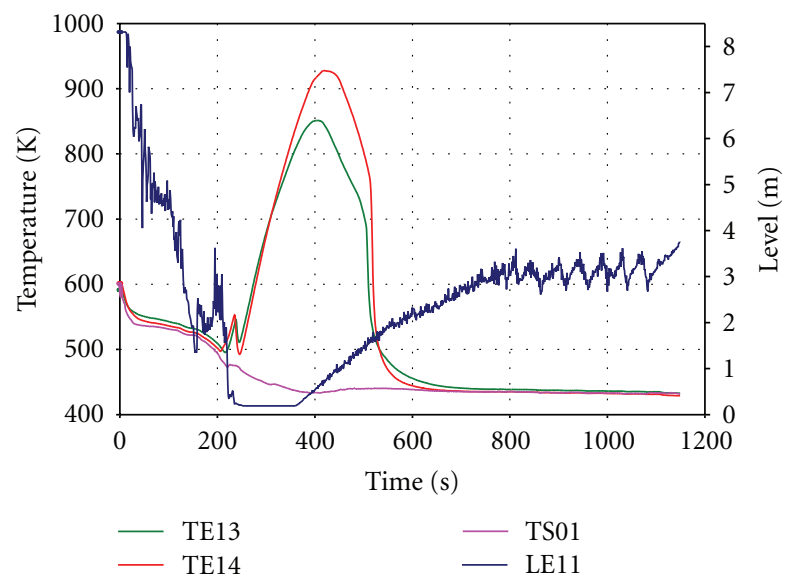

FIgure 16: Cladding temperatures TE13, TE14, saturation temperature (TS01) and coolant collapsed level in the core model (LE11), in $\mathrm{PH} 4-\mathrm{SLB}, 32 \%$ break in the surge line at the hot leg connection.

quantitatively "correct", since the most important test-specific phenomena as pressuriser behaviour during safety valve opening, primary system behaviour during coolant depletion, and refill of the core are well predicted. The qualification level of quantitative prediction is also "good".

Results show that different model approaches applied to the ATHLET, CATHARE, and RELAP5 codes do not influence the quality of predictions in the different types of transients as SBLOCA, LBLOCA, and Transients.

Computer code modelling, development of nodalisations, needs significant users' expertise and experience gained in simulating plant transients, and vice versa, experiences obtained in the development of computer model for facilities can directly be applied to plant models. Nodalisation may also depend on transient type to be simulated. However, users develop, for example, for a facility a "basic" 


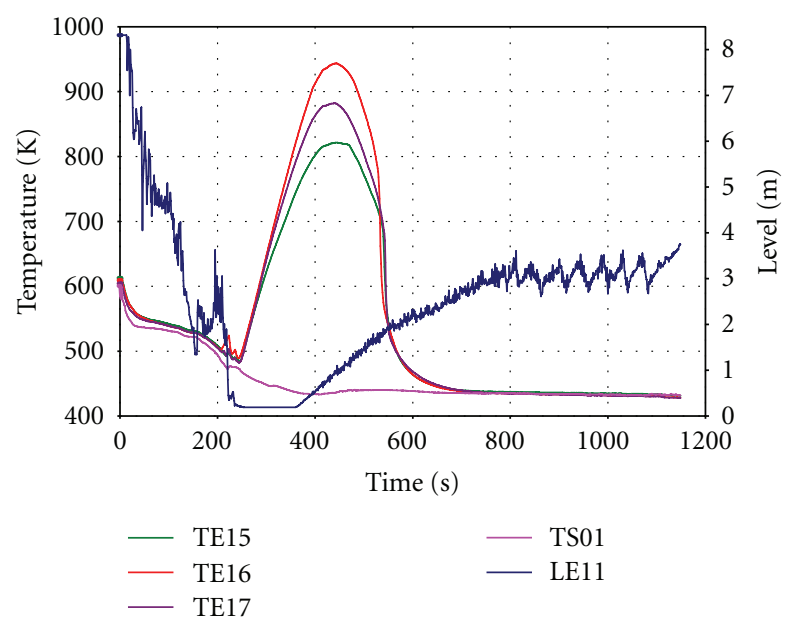

FIgURE 17: Cladding temperatures TE15, TE16, TE17, saturation temperature (TS01) and coolant collapsed level in the core model (LE11), in PH4-SLB, 32\% break in the surge line at the hot leg connection.

nodalisation; however, it should be modified in cases when certain phenomena should be described in detail and properly. Methodology for different codes are different. Experts from Germany, France, and USA helped us in developing nodalisation for ATHLET, CATHARE, and RELAP5, respectively. Results of assessment activities in the PMK-2 projects show that similar quality of transient predictions can be achieved by each of the three codes.

6.1. Example for the Qualitative Assessment. The qualitative assessment by engineering judgement refers to the comparison of the results of a test and the results of a computer code calculation, evaluating the results by visual observation. In other words, the qualitative assessment is made by evaluating and ranking the discrepancies between the measured and calculated parameters. In the practice of the qualitative assessment, the comparison by visual observation is limited to the time variations of parameters. follows.

The qualification of qualitative assessment results is as

(i) Calculation falls within experimental data uncertainty band, which means that the code calculation is qualitatively and quantitatively correct.

(ii) Calculation does not fall within the uncertainty band but shows correct trend. It means that the code calculation is qualitatively correct.

(iii) Calculation lies out of the uncertainty band and does not show correct trend, and the reason is unknown. The result of calculation is not acceptable.

The $\mathrm{OAH}-\mathrm{C} 1,2 \%$ cold leg break test with 2 SITs and 1 HPIS, addresses the study of the effectiveness of the secondary side bleed, to reinitiate the SITs injection and cooldown of the system, after significant loss of the primary coolant, which leads to extensive dryout in the core.

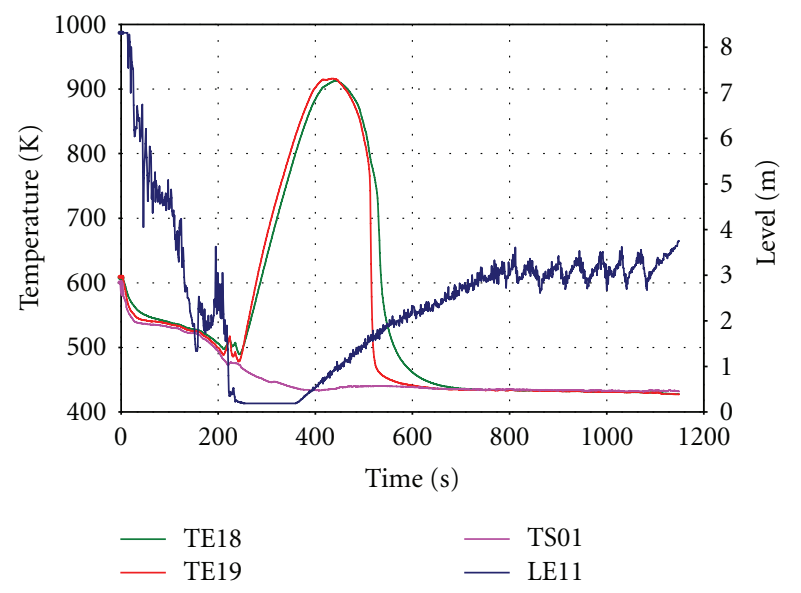

FIgure 18: Cladding temperatures TE18, TE19, saturation temperature (TS01) and coolant collapsed level in the core model (LE11), in PH4-SLB, 32\% break in the surge line at the hot leg connection.

The test is started from the nominal operating parameters of the Paks NPP with availability of 2 SITs, both injecting to the downcomer. After the subcooled blowdown, however, the primary pressure is practically stagnating, and the injection from SITs is initiated by the opening and closing of the BRU-A. Due to the coolant loss, extensive dryout occurs in the core at $1514 \mathrm{~s}$ with a maximum temperature of $742 \mathrm{~K}$. The injection from SITs is reinitiated by secondary bleed through the BRU-A to cool down the system. The validation is focused on the phenomena: mixing and condensation during injection from ECCSs; loop seal behaviour in hot leg and clearance in cold leg; core heat transfer including DNB and dryout; heat transfer in covered and partly covered core; core thermohydraulics.

The code, validated by the test, is the RELAP5/mod3.2.2 Gamma, in the framework of the US NRC CAMP program. The computer code model with the nodalisation scheme is presented in Figure 19.

Results of calculations for the initial conditions and boundary conditions fall into the uncertainty bands of the tests; therefore, the code calculation is qualitatively and quantitatively correct. The same is true for the timing of events, except for the generation of scram. However, it does not affect the overall trend of the time variation of parameters, which are shown in Figures 20, 21, 22, and 23.

Results of transient calculation are as follows.

(i) The overall trend of the time variations of parameters presented in Figures 20 to 23 is well predicted. In the calculation, the BRU-A opens three times in the test, however, two times in the calculation with slightly different times.

(ii) Due to the cold water injection from SITs into the downcomer, direct contact condensation occurs in the downcomer head. The more extensive condensation in the calculation results in higher mass loss 


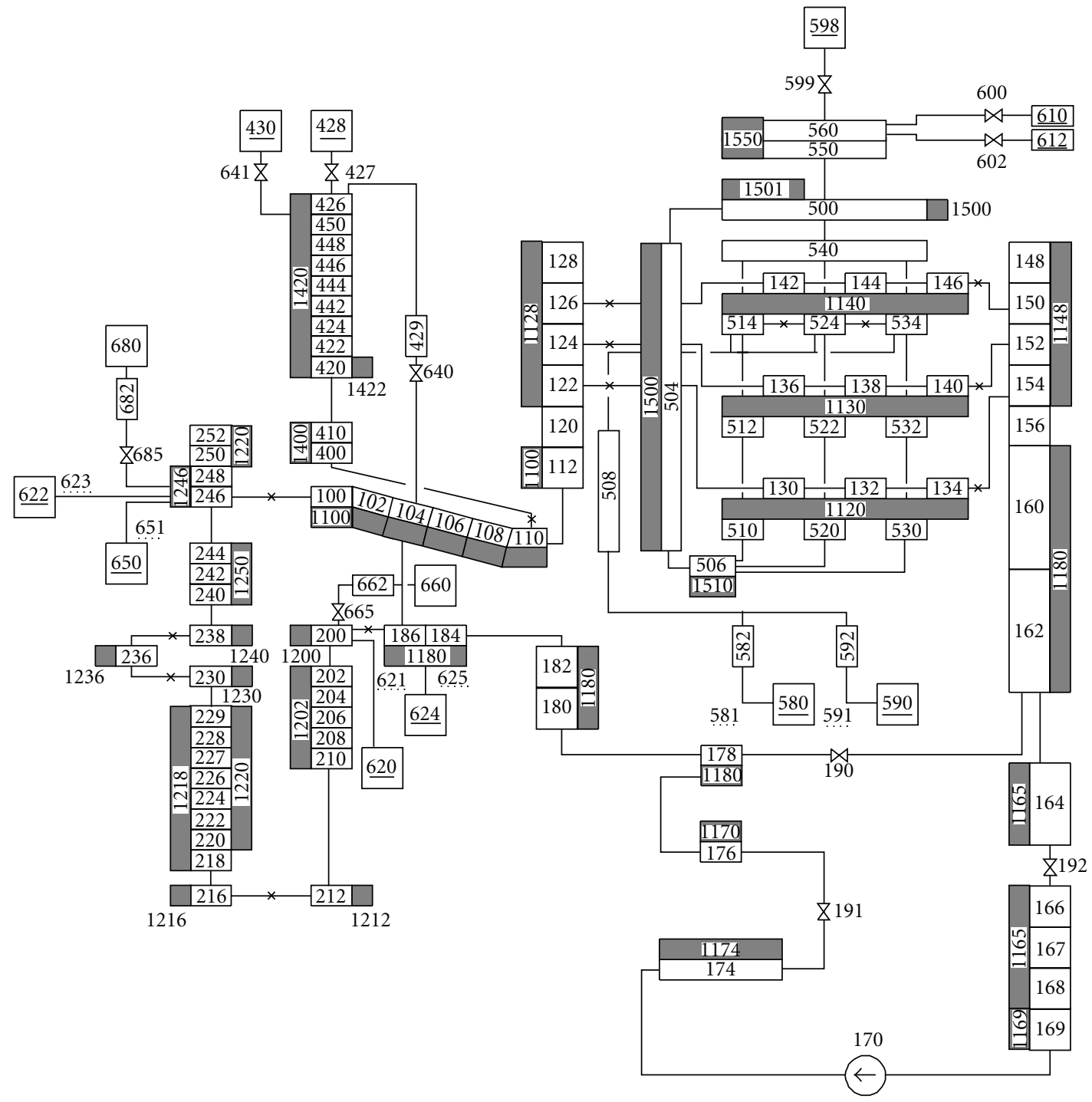

Figure 19: PMK-2 nodalisation scheme for RELAP5/mod3.2.2 Gamma as applied to the OAH-C1 test.

through the break: this indicates that the phenomena mixing and condensation are overpredicted.

(iii) The core heat transfer and especially the timing and value of maximum cladding temperature (1514 s/ $742 \mathrm{~K}$ in the test and $1526 \mathrm{~s} / 726 \mathrm{~K}$ in the calculation) are well predicted (Figure 23).

(iv) The hot leg loop seal behaviour is very well predicted as shown in Figure 22. The deviation in the prediction of timing of cold leg loop seal clearing is $\sim 11 \%$.

6.2. Example for the Quantitative Assessment. The methodology for the qualitative and quantitative assessment of computer code accuracy with applications was presented in several papers [14-16]. The FFT-based method includes two phases as the qualitative and quantitative phases. The time variations of the measured and calculated parameters characterizing the transient are the basis in the qualitative phase and input to the quantitative phase, that is, to the FFTBM (Fast Fourier Transform Based Method) code.

The procedure for the qualitative phase of the assessment is primarily based on OECD/CSNI and US INEL suggestions $[17,18]$. The main steps are as follows:

(i) subdivision of the transient in "phenomenological windows". For each window: specification of key phenomena, identification of "relevant thermal-hydraulic aspects" (RTA), and selection of parameters characterizing the RTAs are given;

(ii) qualitative analysis of the results of the measured and calculated time variations of parameters with the subjective judgments are as follows.

(a) Excellent: the code predicts the parameter qualitatively and quantitatively; the calculation falls within experimental data uncertainty band; 


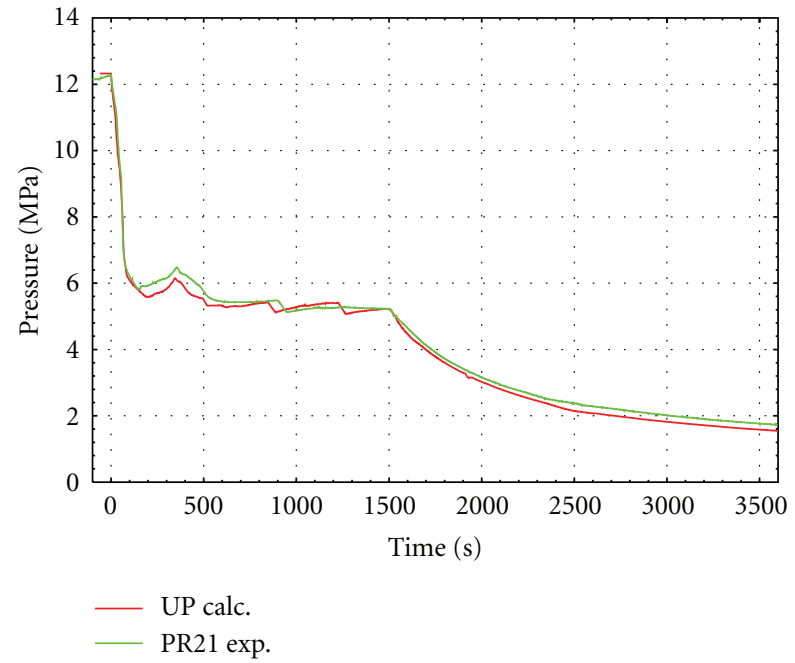

FIGURE 20: Measured and calculated primary pressures (PR21) in OAH-C1 test. Calculation by RELAP5/mod3.2.2 Gamma code.

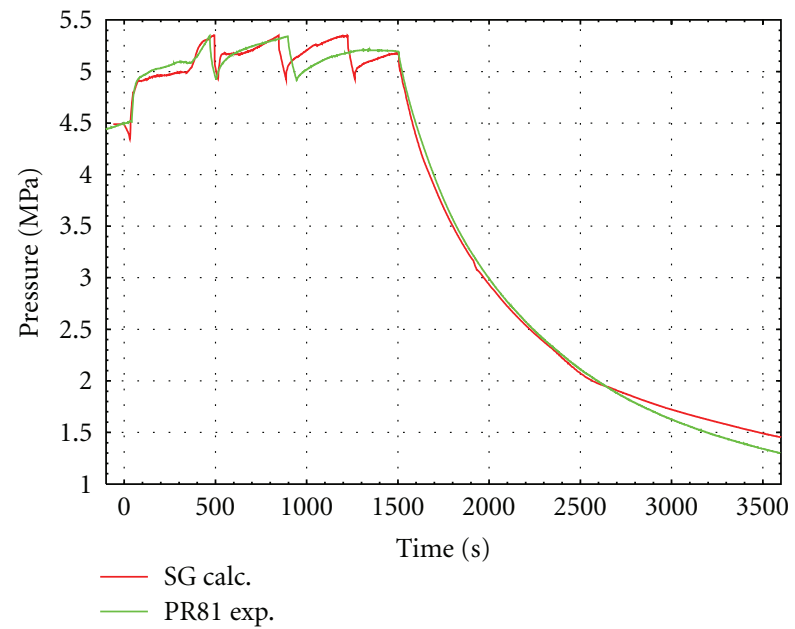

FIGURE 21: Measured and calculated secondary pressures (PR81) in OAH-C1 test. Calculation by RELAP5/mod3.2.2 Gamma code.

the calculation is qualitatively and quantitatively correct.

(b) Reasonable: the code predicts the parameter qualitatively but not quantitatively; the calculation is not within experimental data uncertainty band but shows correct behaviour and trends.

(c) Minimal: the code does not predict the parameter, but the reason is understood and predictable; the calculation does not lie within experimental uncertainty band and does not show correct behaviour and trends.

(d) Unqualified: the code does not predict the parameter, and the reason is not understood; the calculation does not lie within experimental uncertainty band and does not show correct behaviour and trends.

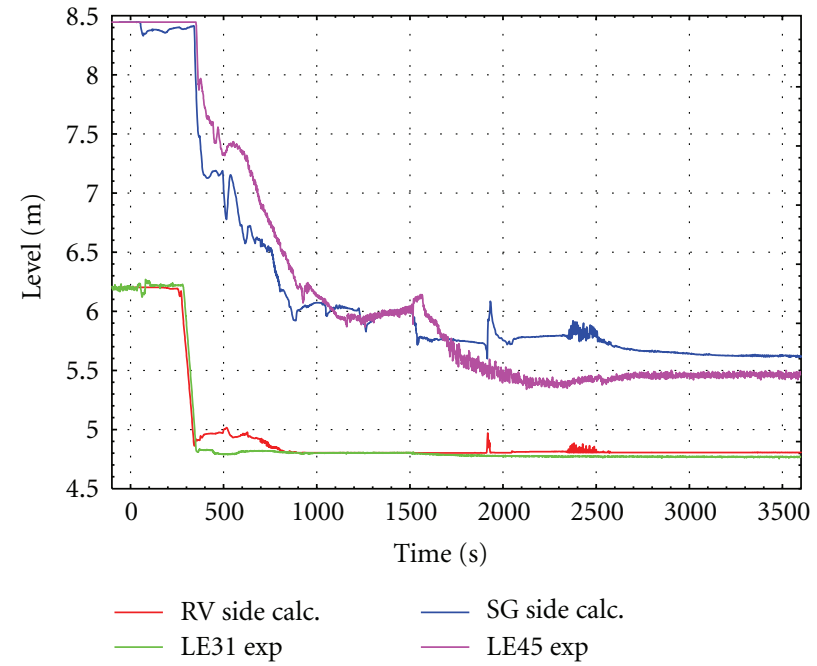

Figure 22: Measured and calculated coolant levels (LE31/LE45) in the hot leg loop seal in OAH-C1 test. Calculation by RELAP5/ mod3.2.2 Gamma code.

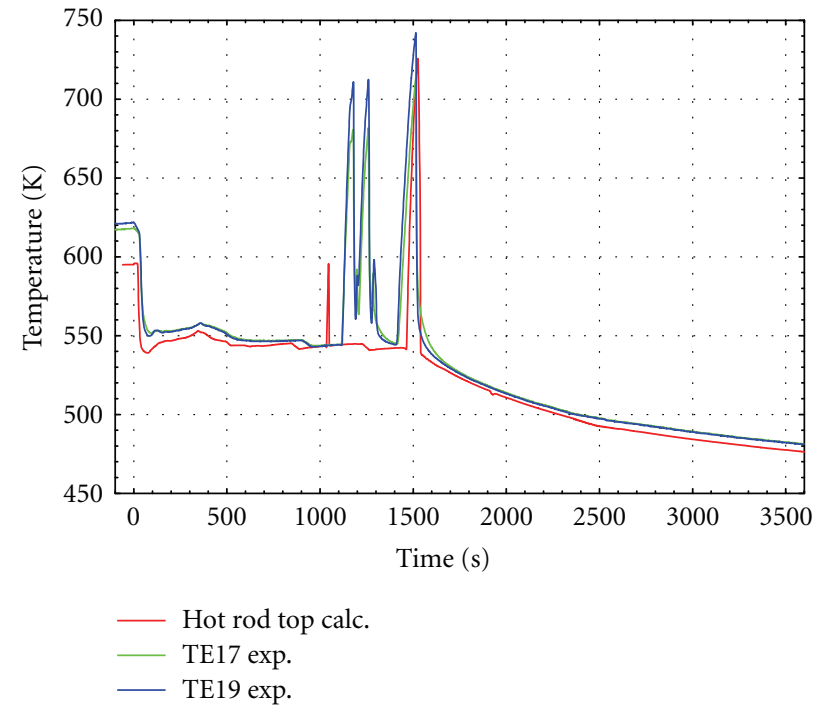

FIgURE 23: Measured and calculated cladding temperatures (TE17, TE19) in OAH-C1 test. Calculation by RELAP5/mod3.2.2 Gamma code.

In the qualitative phase of assessment the definition of "phenomenological windows" and corresponding RTA's is highly influenced by the expertise and practice of user.

The quantitative phase of the FFT-based method [13, 15], with the improvements [12], is presented below. The fast Fourier transform (FFT) is an algorithm that rapidly computes the discrete Fourier transform. To apply it, functions must be identified by a number of values that is a power with base equal to 2, and also sampling theorem should be fulfilled. The fulfilment of the sampling theorem is required to avoid distortion of sampled signals due to aliasing occurrence. Thus if the number of points defining the function in the time domain is NVAL $=2^{m+1}$, then according 
to the sampling theorem the sampling frequency, $f_{s}=$ $2 f_{\max }=\mathrm{NVAL} / T_{d}$, where $T_{d}$ is the transient time duration of the sampled signal and $f_{\max }$ is the maximum frequency component of the signal. The sampling theorem does not hold beyond $f_{\max }$. It can be seen that the selection of the number of points is strictly connected to the sampling frequency. The FFT algorithm determines the number of points, equally spaced, which is a power with base $2(N$ ranges from $2^{9}$ to $2^{12}$ ). Generally, an interpolation is necessary to satisfy this requirement. The FFTBM application implies analysis window $\left(T_{d}\right)$ selection, the number of points (NVAL) determination through the fixed frequency (FFIXminimum maximum frequency of analysis) value selection, the cut-off frequency (FCUT) value determination, and the weights selection. The cut off frequency has been introduced to cut-off spurious contributions.

The FFTBM calculates the measurement-prediction discrepancies in the frequency domain. For the calculation of these discrepancies experimental signal $\left(F_{\exp }(t)\right)$ and error function are needed. The error function in the time domain $\Delta F(t)=F_{\text {cal }}(t)-F_{\exp }(t)$, where $F_{\text {cal }}(t)$ is the calculated signal. The code accuracy quantification for an individual calculated variable is based on amplitudes of discrete experimental and error signal obtained by FFT at frequencies $f_{n}$, where $n=$ $0,1, \ldots, 2^{m}, N=2^{m}$, and $m$ is the exponent $m=8,9,10,11$. These spectra of amplitudes together with frequencies are used for calculation of average amplitude (AA) and weighted frequency (WF) that are the measures of code accuracy.

Normally 14 to 28 variables are selected for accuracy analysis. The most suitable factor for the definition of an acceptability criterion is the total average amplitude $\mathrm{AA}_{\text {tot }}$. With reference to the accuracy of a given calculation, we can define the following acceptability criterion: $\mathrm{AA}_{\text {tot }}<K$, where $K$ is acceptability factor valid for the whole transient and is $K=0.4$. Previous studies showed that

$\mathrm{AA}_{\text {tot }} \leq 0.3$ characterize very good code predictions, $0.3<\mathrm{AA}_{\text {tot }} \leq 0.5$ characterize good code predictions, $0.5<\mathrm{AA}_{\text {tot }} \leq 0.7$ characterize poor code predictions, $\mathrm{AA}_{\text {tot }}>0.7$ characterize very poor code predictions.

The experiment selected to represent quantitative assessment is the PHS-05 SBLOCA test.

In accordance with the methodology described above, the evaluation of code accuracy needs steps as given below, which are input to the FFTBM code and preliminary, qualitative evaluation of code predictions. Data needed are as follows.

Parameters characterizing the transient are selected from the results of calculations performed by the ATHLET, CATHARE, and RELAP5 codes and shown in Table 9.

Time windows, which are time intervals with characteristic phases of transients, are determined by the qualitative evaluation of the results of calculations performed by the codes. The time windows of the selected transient process are as follows:

(i) primary system subcooled: 0 to $350 \mathrm{~s}$,

(ii) reactor model emptying: 350 to $4720 \mathrm{~s}$,
TABLE 9: Selected parameters for comparison in PHS-05 test.

\begin{tabular}{|c|c|c|}
\hline Figure no. & Label & Description \\
\hline 1 & TE15 & $\begin{array}{l}\text { Heater rod surface temperature at core } \\
\text { outlet }\end{array}$ \\
\hline 2 & TE63 & Coolant temperature at core inlet \\
\hline 3 & TE22 & Coolant temperature in upper plenum \\
\hline 4 & TE41 & Coolant temperature at SG inlet \\
\hline 5 & TE42 & Coolant temperature at SG outlet \\
\hline 6 & PR21 & Pressure in upper plenum \\
\hline 7 & PR81 & Pressure in the SG secondary side \\
\hline 8 & LE11 & $\begin{array}{l}\text { Coolant collapsed level in the reactor } \\
\text { model }\end{array}$ \\
\hline 9 & LE71 & Coolant level in the pressuriser \\
\hline 10 & LE31 & $\begin{array}{l}\text { Coolant level in the hot leg loop seal, } \\
\text { reactor side }\end{array}$ \\
\hline 11 & LE45 & Coolant level in the SG hot collector \\
\hline 12 & LE46 & Coolant level in the SG cold collector \\
\hline 13 & LE52 & $\begin{array}{l}\text { Coolant level in the cold leg loop seal, } \\
\text { reactor side }\end{array}$ \\
\hline 14 & MA01 & Integrated mass flow through the break \\
\hline
\end{tabular}

(iii) core overheating: 4720 to $5000 \mathrm{~s}$,

(iv) primary inventory restoration, overfeeding of pressuriser: 5000 to $6997 \mathrm{~s}$.

Table 10 contains the Relevant Thermohydraulic Aspects (RTA) and the system parameters characterizing the RTAs for the selected time windows.

(i) RTA types:

TSE: Time sequence event,

SVP: Single-value parameter,

IPA: Integrated parameters.

(ii) Other columns of the table:

exp: experimental values,

ATHLET: values calculated by ATHLET Mod2.0A,

CATHARE: values calculated by CATHARE2 V1.5,

RELAP: values calculated by RELAP5/mod3.3.

By the use of the data presented above, together with the time variations of parameters of the PHS-05 test, calculated by the ATHLET, CATHARE, and RELAP5 codes, the FFTBM code prepares input forms. The nodalisations applied to the system code calculations are as follows: Figure 24 for ATHLET, Figure 25 for CATHARE, and Figure 19 for RELAP5.

The time windows, which are shown in Table 10, with the relevant thermohydraulic aspects (RTA), are important features of the method. The qualification (Q) based on subjective judgement is as follows: $\mathrm{E}$ (excellent), $\mathrm{R}$ (reasonable), $\mathrm{M}$ (minimal), and $\mathrm{U}$ (unqualified). The overall trend of the transient is not influenced by $\mathrm{M}$ value (which occurs 2, 3, 4 cases for the codes ATHLET, CATHARE, and RELAP5, 


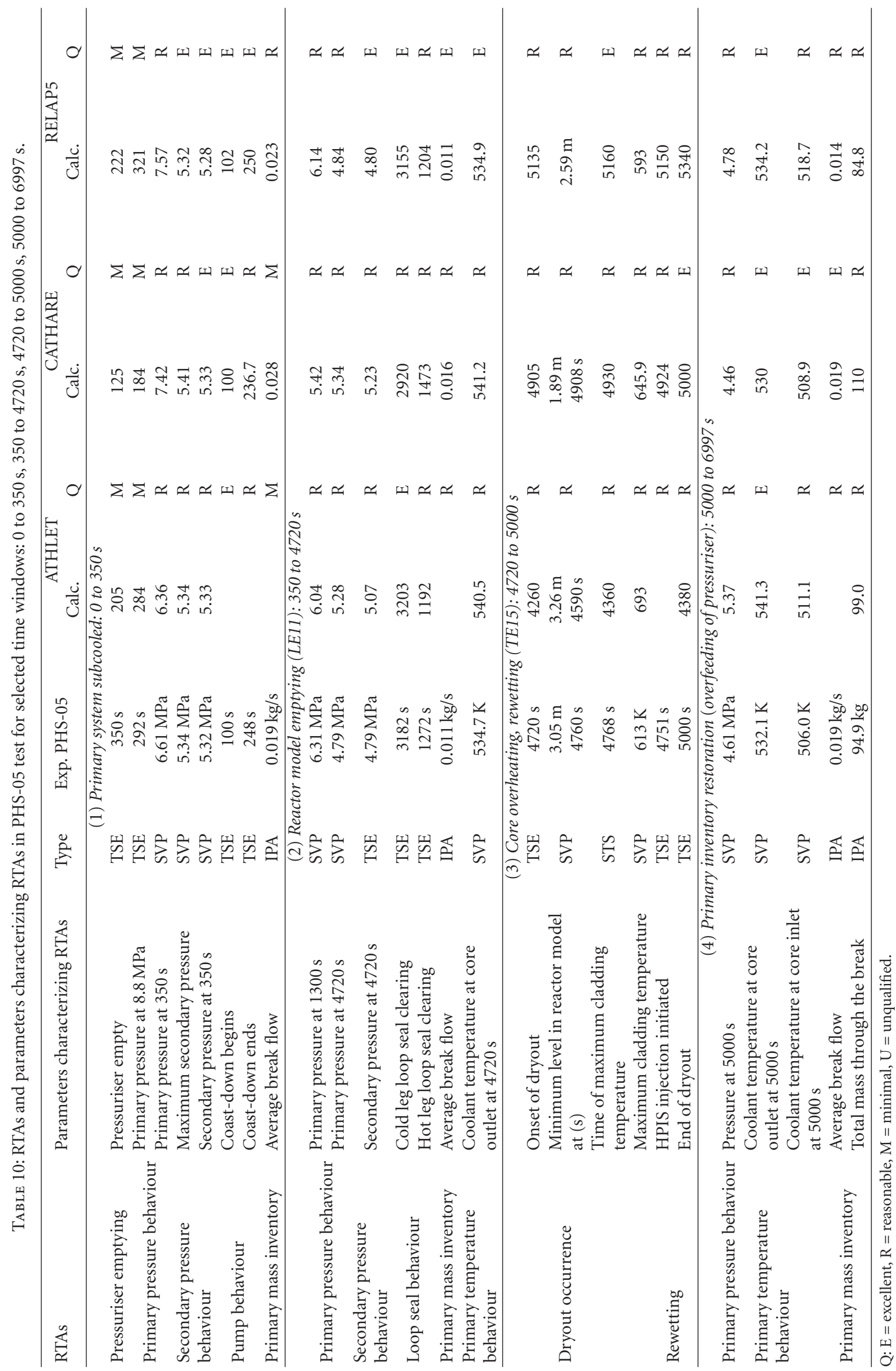




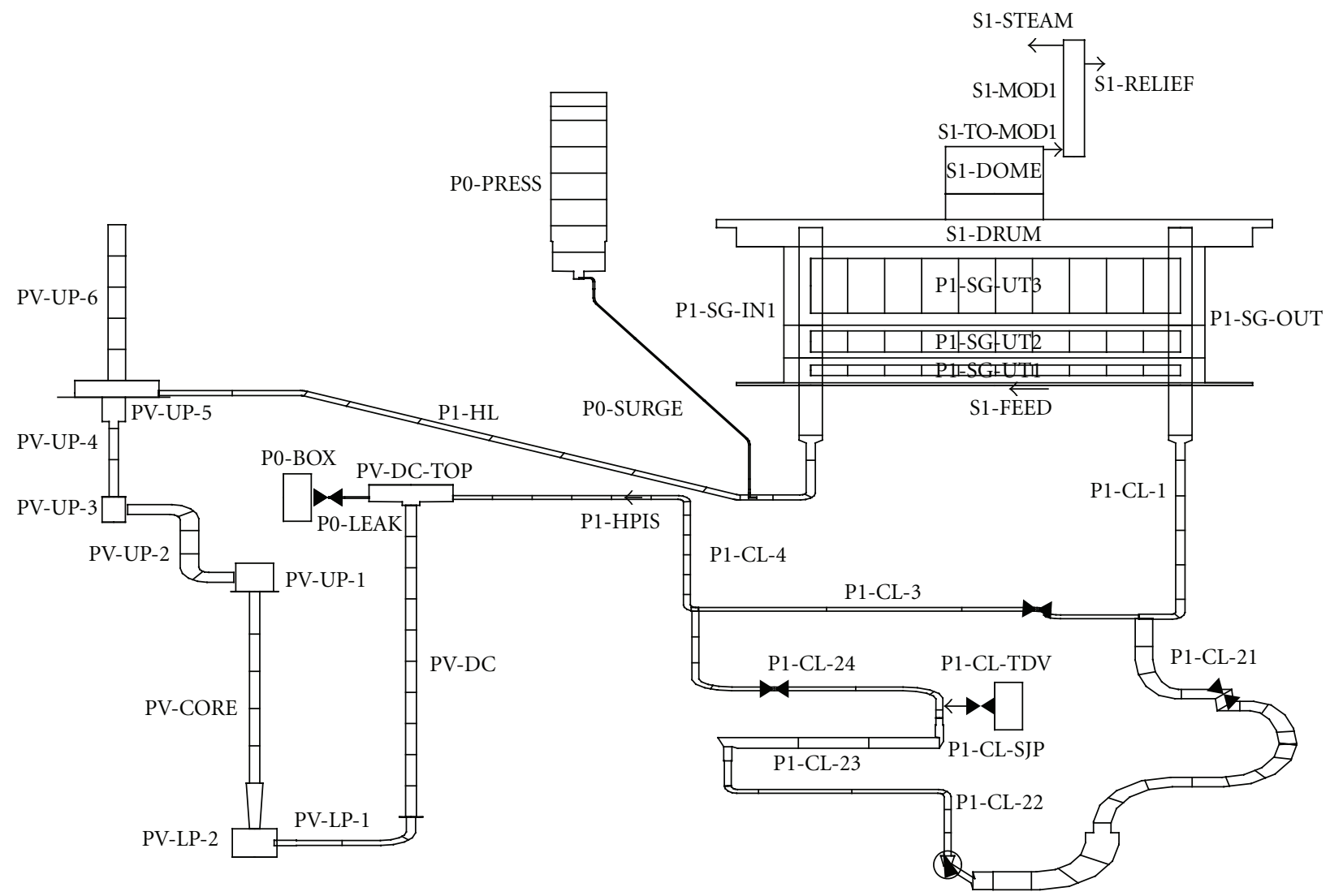

FIGURE 24: Nodalisation scheme for PMK-2 facility for the ATHLET 2.0A applied to PHS-05 experiment.

resp.). Therefore, the prediction is reasonable for all the three codes. It is because the assessment level $\mathrm{M}$ refers only to the "pressuriser empty" and "primary pressure at 8.8 Mpa" and the disagreement does not influence the transient process significantly in the late phase of transient process.

Results of quantitative assessment obtained by the FFTBM code are shown in Table 11. The qualification is "very good".

\section{Conclusions}

The integral-type facilities have great significance, because they can provide experimental information on transients and accidents anticipated to occur in nuclear power plants. In the 1980s the PMK-2 was the first and the only integraltype facility for VVERs. The PMK-2 was later followed by the PACTEL facility for VVER-440 (Finland 1990) and by the ISB and PSB facilities for VVER-1000 (Russia, 1992 and 1998, resp.).

The PMK-2 facility is a full-pressure thermohydraulic model of the primary and partly the secondary circuit of the Paks nuclear power plant of VVER-440/213 type. The overall scaling ratio is $1: 2070$, the elevation scale is $1: 1$, due to the importance of gravitational forces in natural circulation. The available power is $2 \mathrm{MW}$ that allows establishing nominal conditions of the plant. All the VVER-specific design features are included in the design of the facility. The PMK-2 facility satisfies the criteria of the OECD/CSNI Facility and Test Qualification Matrix.

The first PMK-2 experimental data base covers the list of design basis accidents analysed in the Safety Analysis Report of the Paks NPP, as well as practically all test types described in the OECD-VVER cross-reference matrices. The data base consists of 55 tests which address and help to understand all the important aspects of plant system behaviour in accident conditions. Results are available in digital form at the OECD/NEA data bank.

The significance of the PMK-2 experiments mainly consists in creation of a unique, high-quality data base that can be used for code validation in the three main groups of the OECD-VVER code validation matrices, namely, large breaks, small/intermediate leaks, and plant transients. Phenomena simulated at the level required by the validation matrices are as follows: break flow, pressuriser thermohydraulics and surge line hydraulics, heat transfer in SG primary and secondary sides, single- and two-phase natural circulation, mixing and condensation during injection from ECCSs, loop seal behaviour in hot leg and clearance in cold leg, and core heat transfer in clearing DNB and dryout.

PMK-2 test results had continuously been applied to the validation of different versions of ATHLET, CATHARE, and RELAP5, primarily in international frameworks as: IAEA SPEs, US NRC CAMP programme, EU-PHARE, and EUFramework programmes. Altogether, 28 PMK-2 tests were 


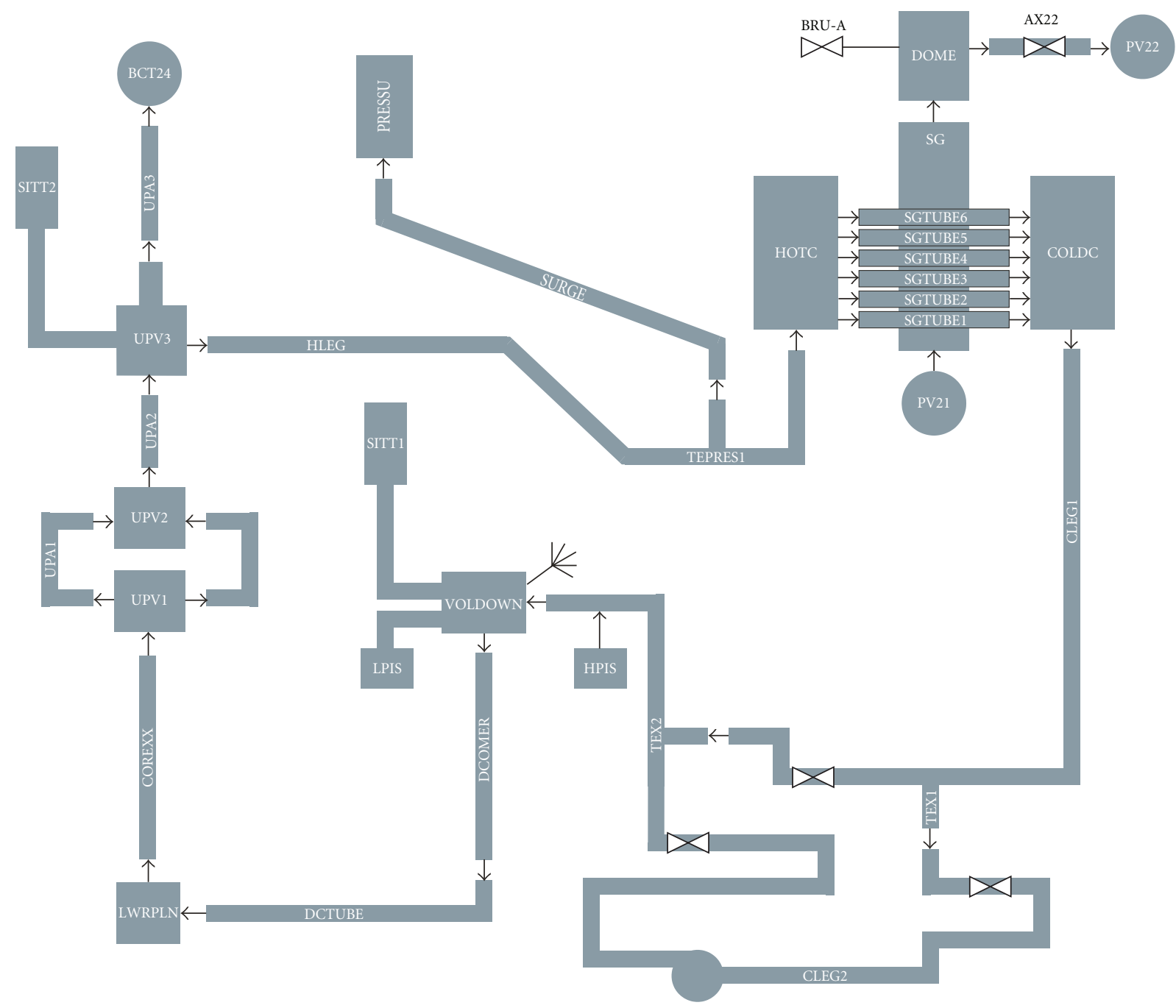

FIgURE 25: Nodalisation scheme for PMK-2 facility for CATHARE2 V1.5 applied to the PHS-05 experiment.

applied to different international code validations. During the 20-year period of PMK-2 projects a scientific school has been established with the participation of experts from 29 countries.

Since the codes applied for safety analysis in Hungary are ATHLET for LBLOCA, RELAP5 for SBLOCA, and transients, as well as CATHARE which is used as an independent tool to support regulatory authority, validation activities in the country are concentrated to these codes. Methodologies of code validation in the PMK-2 projects include both qualitative and quantitative assessments. The qualitative assessment is based on visual observation and engineering judgement of the agreement. The quantitative assessment results are obtained by the Fast Fourier Transform Based Method. Last version of the codes as ATHLET MOD2.0A, CATHARE2 V1.5, and RELAP5/mod3.3 have been validated, selecting representative tests.

Expertise gained in the PMK-2 projects was essential for the national reassessment of the safety and for the preparation of the Final Safety Analysis Report of the Paks nuclear
TABLE 11: The total values of AA and WF.

\begin{tabular}{lcc}
\hline Code & $\mathrm{AA}_{\text {tot }}$ & $\mathrm{WF}_{\text {tot }}$ \\
\hline ATHLET Mod2.0-A & 0.25 & 0.03 \\
CATHARE2 V1.5 & 0.22 & 0.03 \\
RELAP5/mod3.3 & 0.23 & 0.04 \\
\hline
\end{tabular}

The qualification is "very good".

power plant on a high level and played an important role in all the modifications performed in the plant, for example, for EOP development, increase of power, handling of primary to secondary leak, and others.

The PMK-2 projects significantly supported the solution of specific problems encountered during the lifetime of the Paks NPP. They corroborated that there is no need to interconnect the hot and cold legs in the operating plant as it had been proposed by Gidropress; they verified the effectiveness of secondary and primary bleed and feed in a group of EOPS 
like post LOCA cooldown and large break LOCA during cooldown; they continuously supported safety improvement activities in the field of SG tube and SG header ruptures and others.

Hopefully, the PMK-2 data base has significant value for the safety evaluation of all VVER-440/213 type reactors in operation and provides valuable source of scientific information to the nuclear community in the world.

\section{Nomenclature}

AA:

Average amplitude (error function for

AEKI:

AM:

ATWS:

BF:

BRU-A:

CAMP:

CSNI:

DAS:

DBA:

DE:

DNB:

DNBR:

DP:

ECCS:

EFW:

EU:

$f_{\max }$ :

$f_{s}:$

FCUT:

FET:

FFT:

FFTBM:

FFIX:

FL:

GFK:

PAV-GKK:

HA:

HPIS:

HVM:

IAEA:

IBLOCA:

IMPAM:

ISP:

KFKI:

LBLOCA:

LE:

LOCA:

LOFA:

LPIS:

LV:

MCP: $\quad$ Main circulating pump

OM1-MSH: Main steam header-bleed and feed

MTA:

NEA:

NPP:

\section{FFTBM)}

Atomic Energy Research Institute

Accident management

Anticipated transient without scram

Bleed and feed

Steam dump valve

Code Assessment and Maintenance Program

Committee for Safety of Nuclear Installation

Data acquisition system

Design basis accident

Density

Departure from nucleate boiling

Departure from nucleate boiling ratio

Differential pressure

Emergency core cooling system

Emergency feed water

European Union

Maximum frequency component of the signal

Sampling frequency

Cut-off frequency

Valve closure in cold leg

Fast Fourier transform

Fast Fourier transform based method

Minimum-maximum frequency

Flow

Gas in upper plenum

Gas in SG collectors

Hydroaccumulator

High pressure injection system

International Atomic Energy Agency

Intermediate break LOCA

Improved accident management

International standard problem

Central Research Institute for Physics

Large break LOCA

Level

Loss of coolant accident

Loss of flow accident

Low-pressure injection system

Local void

Hungarian Academy of Sciences

Nuclear Energy Agency

Nuclear power plant
NVAL: Number of points in time domain

NVH: High-pressure water-cooled loop

OAH: National Atomic Energy Authority of Hungary

OECD: Organisation for Economic Cooperation and Development

OKKFT: National Middle-Term Safety Research and Development Program

OMFB: National Committee for Technological Development

PARt: Paks Nuclear Power Plant Company

PM: $\quad$ Pump rotor seizure

PMK: Paks model experiment

PR: $\quad$ Pressure

PRISE: Primary to secondary

RTA: Relevant thermohydraulic aspect

SAR: Safety analysis report

SBLOCA: Small break LOCA

SIT: $\quad$ Safety injection tank

SPE: $\quad$ Standard problem exercise

STB: $\quad$ Station blackout

$T_{d}$ : $\quad$ Transient time duration of signal

TLF-BF: Total loss of feed water-bleed and feed

TLFW: Total loss of feed water

UP: $\quad$ Upper plenum

US NRC: United States Nuclear Regulatory

Commission

WF: Weighted frequency (error function for FFTBM).

\section{References}

[1] L. Szabados, G. Ézsöl, L. Perneczky, and I. Tóth, "Final report on the PMK projects. Results of experiments performed in the PMK-2 facility for VVER safety studies," Tech. Rep. vol. I, Akadémiai Kiadó, Budapest, Hungary, 2007.

[2] L. Szabados, "Integral thermal-hydraulics tests for the safety evaluation of VVER-440/213 nuclear reactors and safety code validation," Nuclear Technology, vol. 145, no. 1, pp. 28-43, 2004.

[3] L. Szabados, G. Ézsöl, L. Perneczky et al., "Final report on the PMK projects. Major findings of PMK-2 test results and validation of thermohydraulic system codes for VVER safety studies,” Tech. Rep. vol. 2, Akadémiai Kiadó, Budapest, Hungary, 2009.

[4] M. Ishii and I. Kataoka, "Scaling criteria for PWR's under single-phase and two-phase natural circulation," in Proceedings of the Australian Neuroscience Society Annual Conference (ANS '82), Sydney, Australia, 1982.

[5] OECD/NEA, "Validation matrix for the assessment of thermal-hydraulic codes for VVER LOCA and transients. A report by the OECD support group on the VVER thermal-hydraulic code validation matrix," Nuclear Energy Agency, NEA/CSNI/ R(2001)4, June 2001.

[6] "Simulation of a loss of coolant accident. Results of a standard problem exercise on the simulation of a LOCA," Tech. Rep. IAEA-TECDOC-425, Vienna, Austria, 1987.

[7] "Simulation of a loss of coolant accident with hydroaccumulator injection. Results of the second standard problem exercise on the simulation of a LOCA," Tech. Rep. IAEA-TECDOC477, Vienna, Austria, 1988. 
[8] "Simulation of a loss of coolant accident with a leak on the hot collector of the steam generator. Results of the third standard problem exercise," Tech. Rep. IAEA-TECDOC-586, Vienna, Austria, 1991.

[9] "Simulation of a loss of coolant accident without high pressure injection but with secondary side bleed and feed. Results of the fourth standard problem exercise," Tech. Rep. IAEATECDOC-848, Vienna, Austria, 1995.

[10] L. Perneczky, G. Baranyai, A. Guba, G. Ézsöl, and I. Tóth, "Description and RELAP5 assessment of the PMK-2 CAMPCLB experiment. 2\% cold leg break without HPIS with secondary bleed," Tech. Rep. NUREG/IA-0201, U.S. Nuclear Regulatory Commission, 2001.

[11] F. D'Auria, A. Eramo, M. Frogheri, and G. M. Galassi, "Accuracy quantification in SPE-1 to SPE-4 organized by IAEA," in Proceedings of the 4th ASME/JSME International Conference on Nuclear Engineering (ICONE '96), vol. 3, pp. 461-469, March 1996.

[12] A. Prošek, F. D’Auria, and B. Mavko, "Review of quantitative accuracy assessments with fast Fourier transform based method (FFTBM)," Nuclear Engineering and Design, vol. 217, no. 1-2, pp. 179-206, 2002.

[13] B. Mavko, A. Prošek, and F. D’Auria, "Determination of code accuracy in predicting small-break loca experiment," Nuclear Technology, vol. 120, no. 1, pp. 1-18, 1997.

[14] A. Prošek and B. Mavko, "A tool for quantitative assessment of code calculations with an improved fast Fourier transform based method," Electrotechnical Review, vol. 70, no. 5, pp. 291296, 2003.

[15] R. Bovalini, F. D’Auria, and M. Leonardi, “Qualification of the fast fourier transform based methodology for the quantification of thermohydraulic system code accuracy," DCMN_University of Pisa, NT194 (92), 1992.

[16] F. D'Auria, M. Leonardi, and R. Pochard, "Methodology for the evaluation of thermohydraulic codes accuracy," in Proceedings of the International Conference on New Trends in Nuclear System Thermohydraulics, pp. 467-477, Pisa, Italy, 1994.

[17] H. Holmström, "Quantification of code uncertainties," in Proceedings of the Organisation for Economic Co-operation and Development/Committee on the Safety of Nuclear Installations (OECD/CSNI '92), Aix-en-Provence, France, 1992.

[18] R. R. Schultz, "Methodology for quantifying calculational capability of RELAP5/mod3 code for SBLOCAs, LBLOCAs and operational transients," in Proceedings of the CAMP I Meeting, Villigen, Switzerland, 1992. 

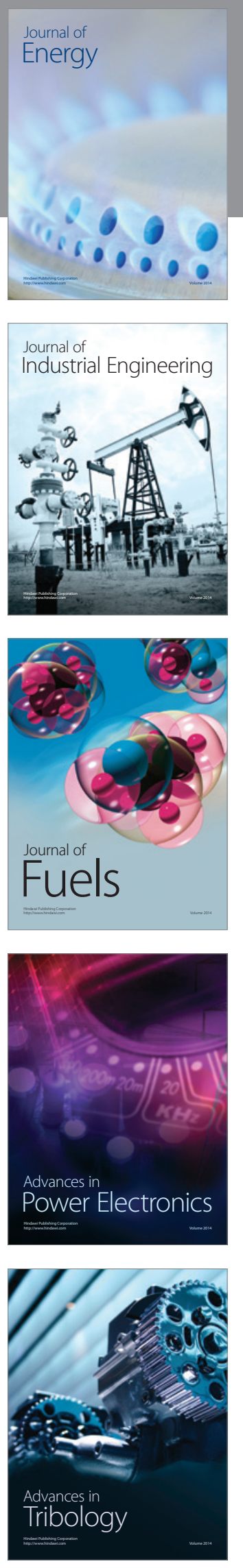
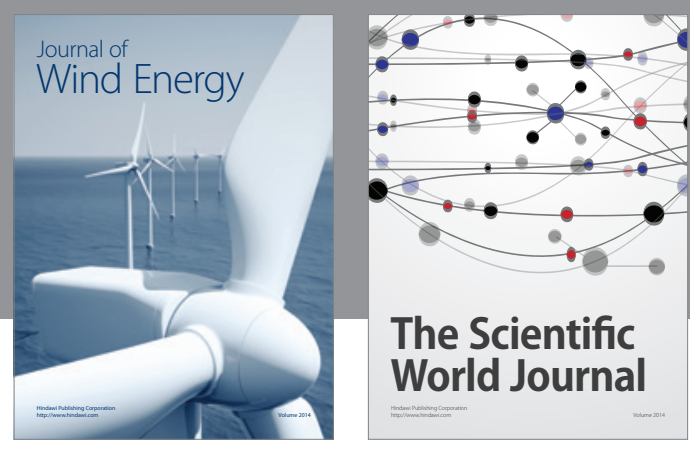

The Scientific World Journal

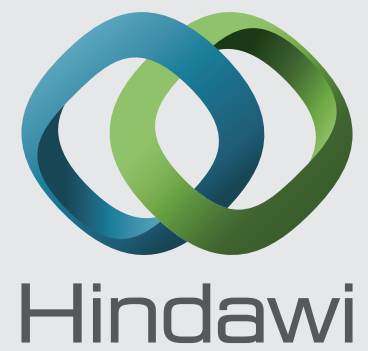

Submit your manuscripts at http://www.hindawi.com
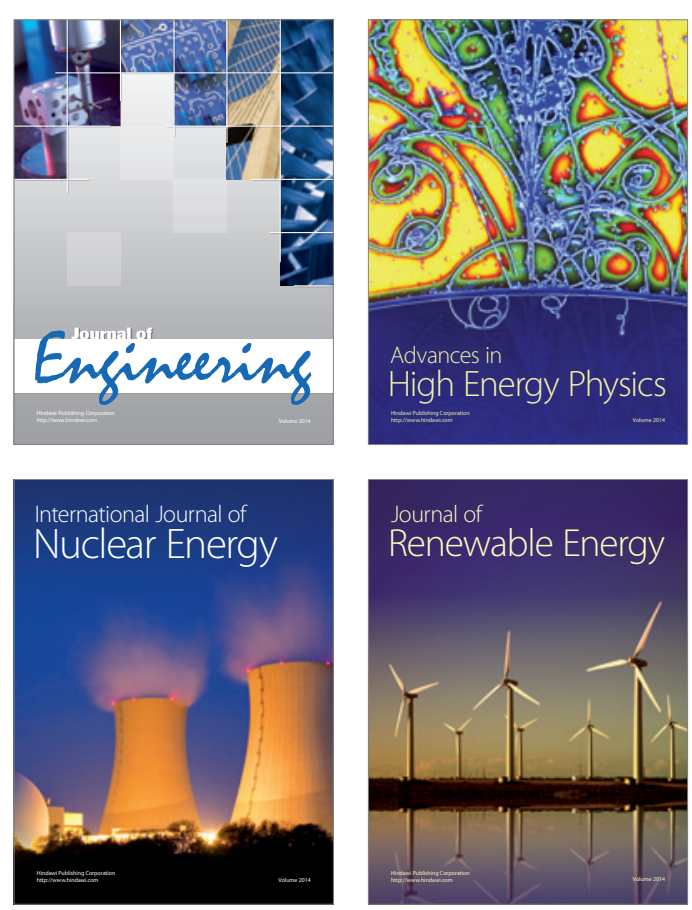

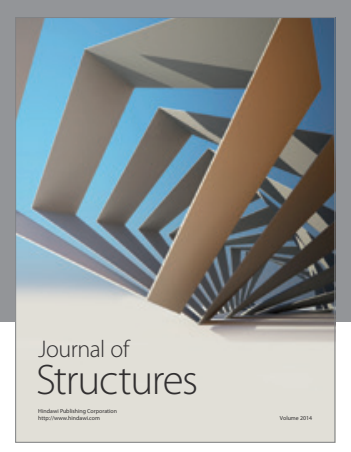

Rotating
Mechinery
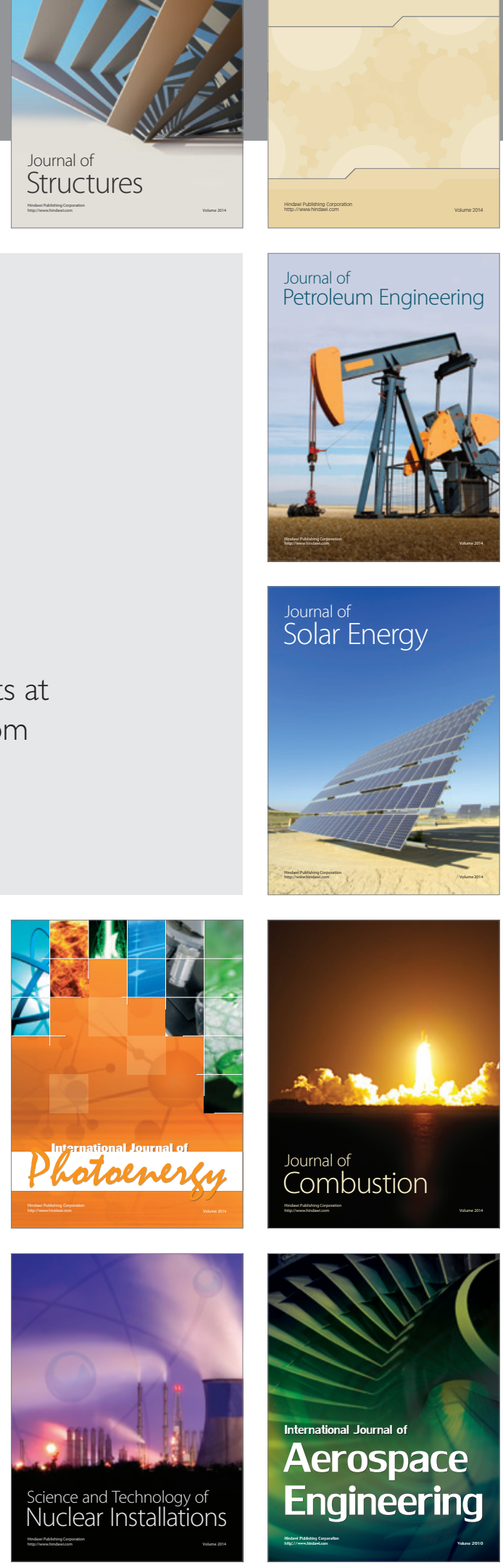